\title{
Competition and Productivity Growth in South Africa
}

\author{
Philippe Aghion, Matias Braun, and Johannes Fedderke
}

CID Working Paper No. 132

August 2006

(C) Copyright 2006 Philippe Aghion, Matias Braun, Johannes Fedderke, and the President and Fellows of Harvard College

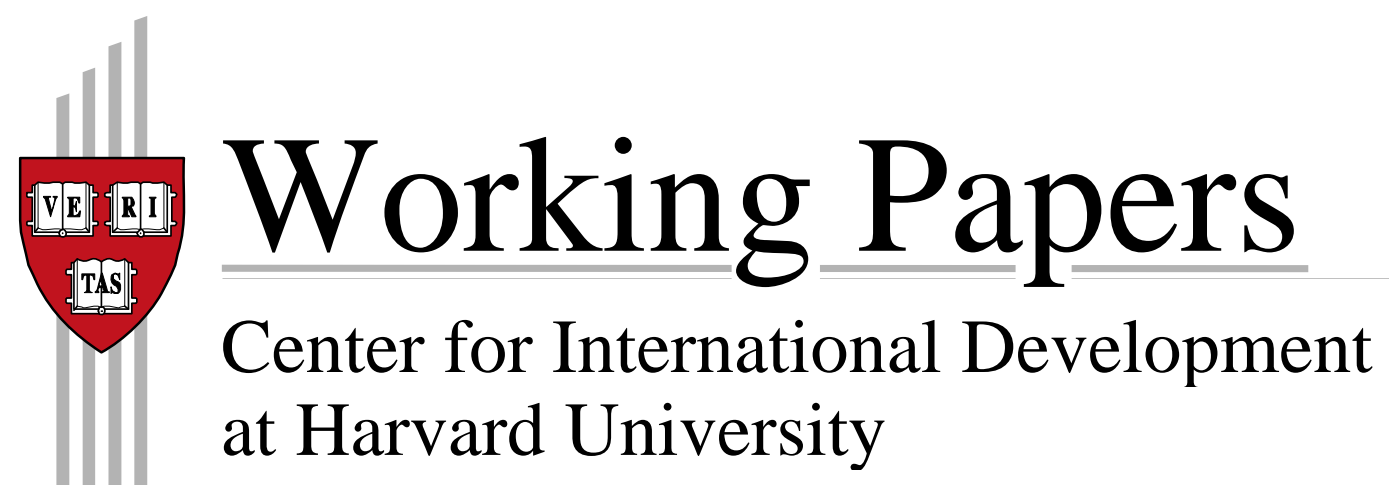




\title{
Competition and Productivity Growth in South Africa
}

\author{
Philippe Aghion ${ }^{1}$, Matias Braun ${ }^{2}$, and Johannes Fedderke ${ }^{3}$
}

DRAFT, August 2006. Subject to further revision

\begin{abstract}
Using three different panel data sets, the authors show: (i) that mark-ups are significantly higher in South African manufacturing industries than they are in corresponding industries worldwide; (ii) that competition policy (i.e. a reduction of markups) should have largely positive effects on productivity growth and employment in South Africa.
\end{abstract}

Keywords: South Africa, Competition, Mark-ups

JEL Codes: O55, L40, O40

This paper is part of the South Africa Growth Initiative. The Center for International Development has convened an international panel of economists and international experts from Harvard University, the Massachusetts Institute of Technology, the University of Michigan, and other institutions to work with South African economists to study that country's constraints to and opportunities for accelerated growth. This project is an initiative of the National Treasury of the Republic of South Africa within the government's Accelerated and Shared Growth Initiative (ASGI-SA), which seeks to consolidate the gains of post-transition economic stability and accelerate growth in order to create employment and improve the livelihoods of all South Africans.
1) Harvard University
2) UCLA
3) University of Cape Town 


\title{
Competition and Productivity Growth in South Africa Philippe Aghion, Matias Braun† and Johannes Fedderke ${ }^{\ddagger}$ \\ June $2006^{\S}$
}

\begin{abstract}
Using three different panel data sets, we show: (i) that mark-ups are significantly higher in South African manufacturing industries than they are in corresponding industries worldwide; (ii) that competition policy (i.e a reduction of mark-ups) should have largely positive effects on productivity growth and employment in South Africa.
\end{abstract}

\section{Introduction}

Recent empirical studies (e.g Nickell (1996), Blundell et al (1999), Aghion et al (2005)), have pointed to a positive effect of product market competition on productivity growth, particularly at low levels of competition. In this paper we explore three different data sets to: (i) first, compare product market competition in South African manufacturing firms and sectors to that in the corresponding sectors worldwide; (ii) second, assess the effect on productivity growth and aggregate employment in South Africa of increasing product market competition.

The three data sets are respectively: (i) industry-level panel data for SA and more than 100 countries since the mid-1960s, from UNIDO; (ii) industry-level panel data over the period 1970-2004 from the TIPS database; (iii) firm-level panel data since the early 1980's from publicly listed companies. Product market competition is measured inversely by the ratio of value added (net of total wages) over output or sales or assets. Productivity growth is computed as the growth rate of real local currency value added per worker.

Our main findings can be summarized as follows: (a) consistently over the three data sets, mark-ups are significantly higher in South African industries than they are in corresponding industries worldwide. In particular, the profitability margins as computed from the

\footnotetext{
*Harvard University

${ }^{\dagger} \mathrm{UCLA}$

¥University of Cape Town

$\S$ First draft - subject to further revision.
} 
listed firms sample, is more than twice as large in South Africa than it is in other countries. Moreover, there is no declining trend in the markup differential between SA and other countries over the recent period; (b) higher past mark ups are associated with lower current productivity growth rates and with lower current employment. In particular, a ten percent reduction in SA mark-ups would increase productivity growth in SA by 2 to $2.5 \%$ per year, and a 0.1 unit reduction in the Lerner index should increase SA employment by 3400 employees; (c) finally, when introducing a quadratic term on the RHS of the growth regression, we find the same kind of inverted-U relationship between competition and growth as for the UK and other countries.

The paper is organized as follows. Section 2 presents a simple model to analyze the relationship between competition and growth, and to describe the "escape competition" effect that underlies the positive correlation between competition and growth. Section 3 presents the empirical methodology, the three data sets and the measures used in our regressions. Section 4 shows the mark-up comparisons. Section 5 outlays our growth and employment regressions. Finally, Section 6 outlays some preliminary conclusions.

\section{Theory: the escape competition effect}

We consider a domestic economy which takes as given the rate of innovation in the rest of the world. ${ }^{1}$ Thus the world technology frontier is also moving at a constant rate, with productivity $\bar{A}_{t}$ at the end of period $t$, satisfying:

$$
\bar{A}_{t}=\gamma \bar{A}_{t-1}
$$

where $\gamma>1$.

\footnotetext{
${ }^{1}$ This section borrows unrestrainedly from Aghion-Howitt (2004), which itself builds on Aghion-Harris-Vickers (1997), Aghion-Harris-Howitt-Vickers (2001), and the discrete time version of the Schumpeterian growth model (see Acemoglu et al. (2002)) used in the previous chapters.
} 
In each country, the final good is produced using the same kind of technology as in the previous sections, with a continuum of intermediate inputs and we normalize the labor supply at $L=1$, so that:

$$
y_{t}=\int_{0}^{1} A_{i t}^{1-\alpha} x_{i t}^{\alpha} d i
$$

where, in each sector $i$, only one firm produces intermediate input $i$ using final good as capital according to a one-for-one technology.

In each sector, the incumbent firm faces a competitive fringe of firms that can produce the same kind of intermediate good, although at a higher unit cost. More specifically, we assume that at the end of period $t$, at unit cost $\chi$, where we assume $1<\chi<1 / \alpha<\gamma \chi$, a competitive fringe of firms can produce one unit of intermediate input $i$ of a quality equal to $\min \left(A_{i t}, \bar{A}_{t-1}\right)$, where $A_{i t}$ is the productivity level achieved in sector $i$ after innovation has had the opportunity to occur in sector $i$ within period $t$.

In each period $t$, there are three types of sectors, which we refer to as type- $j$ sectors, with $j \in\{0,1,2\}$. A type- $j$ sector starts up at the beginning of period $t$ with productivity $A_{i t-1}=\bar{A}_{t-1-j}$, that is, $j$ steps behind the current frontier $\bar{A}_{t-1}$. The profit flow of an incumbent firm in any sector at the end of period $t$, will depend upon the technological position of that firm with regard to the technological frontier at the end of the period.

Between the beginning and the end of the current period $t$, the incumbent firm in any sector $i$ has the possibility of innovating with positive probability. Innovations occur step-by-step: in any sector an innovation moves productivity upward by the same factor $\gamma$. Incumbent firms can affect the probability of an innovation by investing more in $R \& D$ at the beginning of the period. Namely, by investing the quadratic R\&D effort $\frac{1}{2} \gamma A_{i t-1} \mu^{2}$ incumbent an firm $i$ in a type- 0 or type-1 sector, innovates with probability $\mu$. However, innovation is assumed to be automatic in type-2sectors, which in turn reflects a knowledge externality from more advanced sectors which limits the maximum distance of any sector to the technological frontier. 
Now, consider the R\&D incentives of incumbent firms in the different types of sectors at the beginning of period $t$. Firms in type- 2 sectors have no incentive to invest in R\&D since innovation is automatic in such sectors. Thus

$$
\mu_{2}=0
$$

where $\mu_{j}$ is the equilibrium R\&D choice in sector $j$.

Firms in type- 1 sectors, that start one step behind the current frontier at $A_{i t-1}=\bar{A}_{t-2}$ at the beginning of period $t$, end up with productivity $A_{t}=\bar{A}_{t-1}$ if they successfully innovate, and with productivity $A_{t}=\bar{A}_{t-2}$ otherwise. In either case, the competitive fringe can produce intermediate goods of the same quality but at cost $\chi$ instead of 1 , which in turn, as in section 2 above, the equilibrium profit is equal to

$$
\pi_{t}=A_{t} \delta(\chi)
$$

with

$$
\delta(\chi)=(\chi-1)(\chi / \alpha)^{\frac{1}{\alpha-1}}
$$

2. Thus the net rent from innovating for a type- 1 firm is equal to

$$
\left(\bar{A}_{t-1}-\bar{A}_{t-2}\right) \delta(\chi)
$$

${ }^{2}$ This, in turn, follows immediately from the fact that

$$
\frac{\partial y_{t}}{\partial x_{i t}}=\chi=p_{i t}
$$

which in turn implies that in equilibrium

$$
x_{i t}=\left(\frac{\chi}{\alpha}\right)^{\frac{1}{\alpha-1}} A_{i t} .
$$

We then simply substitute for $x_{i t}$ in the expression for profit $\pi_{t}$, namely

$$
\pi_{t}=\left(p_{i t}-1\right) x_{i t}=(\chi-1)\left(\frac{\chi}{\alpha}\right)^{\frac{1}{\alpha-1}} A_{i t} .
$$


and therefore a type-1 firm will choose its R\&D effort to solve:

$$
\max _{\mu}\left\{\left(\bar{A}_{t-1}-\bar{A}_{t-2}\right) \delta(\chi) \mu-\frac{1}{2} \gamma \bar{A}_{t-2} \mu^{2}\right\}
$$

which yields

$$
\mu_{1}=\left(1-\frac{1}{\gamma}\right) \delta(\chi)
$$

In particular an increase in product market competition, measured as an reduction in the unit cost $\chi$ of the competitive fringe, will reduce the innovation incentives of a type- 1 firm. This we refer to as the Schumpeterian effect of product market competition: competition reduces innovation incentives and therefore productivity growth by reducing the rents from innovations of type- 1 firms that start below the technological frontier. This is the dominant effect, both in IO models of product differentiation and entry, and in basic endogenous growth models. Note that type- 1 firms cannot escape the fringe by innovating: whether they innovate or not, these firms face competitors that can produce the same quality as theirs at cost $\chi$. As we shall now see, things become different in the case of type-0 firms.

Firms in type-0 sectors, that start at the current frontier, end up with productivity $\bar{A}_{t}$ if they innovate, and stay with their initial productivity $\bar{A}_{t-1}$ if they do not. But the competitive fringe can never get beyond producing quality $\bar{A}_{t-1}$. Thus, by innovating, a type- 0 incumbent firm produces an intermediate good which is $\gamma$ times better than the competing good the fringe could produce, and at unit cost 1 instead of $\chi$ for the fringe. Our assumption $\frac{1}{\alpha}<\gamma \chi$ then implies that competition by the fringe is no longer a binding constraint for an innovating incumbent, so that its equilibrium profit post-innovation, will simply be the profit of an unconstrained monopolist, namely:

$$
\pi_{t}=\bar{A}_{t} \delta(1 / \alpha)
$$

On the other hand, a type-0 firm that does not innovate, will keep its productivity equal to $\bar{A}_{t-1}$. Since the competitive fringe can produce 
up to this quality level at cost $\chi$, the equilibrium profit of a type- 0 firm that does not innovate, is equal to

$$
\pi_{t}=\bar{A}_{t-1} \delta(\chi)
$$

A type-0 firm will then choose its R\&D effort to:

$$
\max _{\mu}\left\{\left[\bar{A}_{t} \delta(1 / \alpha)-\bar{A}_{t-1} \delta(\chi)\right] \mu-\frac{1}{2} \gamma \bar{A}_{t-1} \mu^{2}\right\}
$$

so that in equilibrium

$$
\mu_{0}=\delta(1 / \alpha)-\frac{1}{\gamma} \delta(\chi)
$$

In particular an increase in product market competition, i.e a reduction in $\chi$, will now have a fostering effect on R\&D and innovation. This, we refer to as the escape competition effect: competition reduces pre-innovation rents of type- 0 incumbent firms, but not their post-innovation rents since by innovating these firms have escaped the fringe. This, in turn. induces those firms to innovate in order to escape competition with the fringe.

The combination of these two effects explains the inverted- $U$ relationship between competition and growth which we observe in most countries. However, if we just look for a linear relationship between productivity growth and product market competition, we generally find that the escape competition effect dominates. Both findings are confirmed when restricting attention to SA industry- or firm-level panel data as we shall see in the next sections.

\section{Empirical methodology, data, and measurement}

\subsection{Productivity growth, pricing power and mark-ups}

Our interest lies in the link between productivity growth and competitive pressure in industries. We proceed by the estimation of the general empirical specification given by:

$$
\text { Pgrowt }_{i t}=\alpha+\beta P C M_{i t}+I_{i}+I_{t}+\varepsilon_{i t},
$$


where Pgrowth $h_{i t}$ denotes a measure of productivity growth in sector $i$ at time $t, P C M_{i t}$ is a measure of competitive pressure in sector $i$, and $I_{i}$ and $I_{t}$ stand for industry and year fixed effects.

Two empirical measures for productivity growth are employed in the analysis: labour productivity growth, as well as total factor productivity growth as given by the Solow residual.

The extent of competitive pressure in an industry is proxied by the pricing power evident in the industry. We pay atention to the possbility of alternative measures of pricing power, as well as the existence of a literature devoted to the estimation of the precise magnitude of the mark-up. Thus we follow Aghion et al (2005) in computing the extent of pricing power in an industry directly, by means of a proxy of the Lerner index. The study employs two proxies of the Lerner index, one given by the differential between value added and the total wage bill as a proportion of gross output:

$$
P C M 1=\frac{\text { valueadded }- \text { totalwages }}{\text { sales }}
$$

the second as the difference between output and both wage and capital costs as a proportion of output::

$$
P C M 2=\frac{p Y-w L-r K}{p Y}
$$

where $p Y$ denotes nominal GDP, $w$ the nominal wage rate, $L$ the number of workers, $r$ denotes the nominal interest rate less inflation plus the sectoral depreciation rate of capital,and $K$ the nominal capital stock.

In addition, following the contributions by Hall (1990) and Roeger (1995) we also estimate the magnitude of the mark-up by means of:

$$
\begin{aligned}
N S R & =\Delta(p+q)-\alpha \cdot \Delta(w+l)-(1-\alpha) \cdot \Delta(r+k) \\
& =(\mu-1) \cdot \alpha \cdot[\Delta(w+l)-\Delta(r+k)]
\end{aligned}
$$

where $\mu=P / M C$, with $P$ denoting price, and $M C$ denoting marginal cost. Under perfect competition $\mu=1$, while imperfectly competitive 
markets allow $\mu>1 . \Delta$ denotes the difference operator, lower case denotes the natural log transform, $q, l$, and $k$ denote real value-added, labour, and capital inputs, and $\alpha$ is the labour share in value-added. Details are provided in an Appendix on methodolgical issues surrounding the estimation of mark-ups - see section 7 . below.

Finally, for firm level data we also add a range of measures of profitability.

\subsection{Data}

This study employs three distinct sources of data. Confronted with gaps in firm-level data over the past ten years, we use:

1. Industry-level panel data for South Africa and for more than 100 countries since the mid 1960s is obtained from UNIDO's International Industry Statistics 2004. This dataset contains yearly information on output, value added, total wages, and employment for 27 different manufacturing industries in more than 100 countries since the mid 1960s. > From these data we compute price-cost margins by means of equation (2). Real labor productivity growth is measured as the growth rate of real local currency value added per worker.

2. Firm-level (Worldscope) evidence from publicly listed companies. The firm-level evidence is based on Worldscope data for publicly-listed companies in 56 different countries since the early 1980s. The dataset contains yearly balance sheet and P\&L items, and other basic firm characteristics. Margins are computed by means of equation (2), and real labor productivity growth as the growth rate of real local currency sales per worker. The firm-level data are truncated at the $5 \%$ level in order to avoid the results being driven by a few outliers.

3. Industry-level panel data for South Africa from the TIPS database. The data employed for this study focus on the three digit 
manufacturing industries, over the 1970-2004 period. Variables for the manufacturing sector include the output, capital stock, and labour force variables and their associated growth rates. Data are obtained from the Trade and Industrial Strategies data base. We employ a panel data set for purposes of estimation, with observations from 1970 through 2004. The panel employs data for the 28 three-digit SIC version 5 manufacturing industries in the South African economy for which data is available. Due to problems with data availability a number of sectors have been omitted. These sectors are Tobacco, Coke and refined petroleum products, Television \& communications equipment, Professional \& scientific equipment and Other transport equipment. In addition, due to missing concentration ratios we have also omitted the Other chemicals sector. The list of sectors included in the panel is that specified in Table 1 . This provides a $28 \times 28$ panel with a total of 784 observations.

One may question our use of two alternative industry-level panel data sets, namely UNIDO and TIPS. The advantage of the former is that it covers a larger number of countrries. The advantage of the latter is that it is more detailed on South Africa.

INSERT TABLE 1 ABOUT HERE.

There are questions over the reliability of industry data post-1996. Since the last manufacturing survey was undertaken in 1996, data post-1996 have been disaggregated from the 2-digit sector level on the basis of a single input-output table. The large sample manufacturing survey of 2001 does not appear to have been incorporated into the data, and moreover the 2001 survey has not released the labour component of the survey. The reliability of the data has suffered as a result of this data collection strategy. This is evident from the evidence presented in Table 2, which reports standard deviations of the computed mark-ups for this study. We report only the standard deviations for computed mark-ups, since the measure summarises the output, capital and labour dimensions in the manufacturing sector. Standard deviations increase substantially post-1996 for all sectors, and increase even 
mnore markedly after 2000. In the instance of some sectors (eg. Rubber propducts), the increase is of very substantial magnitude. This reflects increased underlying volatitility in the underlying series from which the mark-ups are computed.

INSERT TABLE 2 ABOUT HERE.

In interpreting the results that follow, it must be borne in mind that reliability of all results based on industry data are likely to decline substantially after 1996. There is no adequate means of compensating for the absence of data collection for the manufacturing sector, and after having collected manufacturing censuses on a bi-annual basis since 1917, South Africa simply ceased doing do since 1996.

\section{Higher mark-ups in South Africa}

The objective of this section is to explore the intensity of competition in South African manufacturing industry. We find consistent evidence of pricing power in South African industry that is greater than international comparators, and which is non-declining over time. In this our results are consistent with those reported in Fedderke, Kularatne and Mariotti (2006). Results prove to be robust across:

- Three distinct data sets, covering both industry level data as well as firm-level evidence.

- Two proxies of the Lerner index, given either by the differential between value added and the total wage bill as a proportion of output, or the difference between output and both wage and capital costs as a proportion of output.

- Alternative measures of firm profitability.

- The measure of mark-up of price over marginal cost of production as suggested by section 3 ..

- The level of aggregation for industry, or firm size. 


\subsection{The Industry-level (UNIDO) panel data for South Africa}

We compute price-cost margins as given by equation (2), while real labor productivity growth is measured as the growth rate of real local currency value added per worker.

Table 3 presents the measures of competition and productivity for each manufacturing industry in South Africa. Due to data availability the price-cost margins we compute differ in two mayor respects from the Lerner index traditionally used to gauge the degree of competition: the fact that we use average instead of marginal costs, and that we do not take into account the payment to physical capital. ${ }^{3}$

INSERT TABLE 3 ABOUT HERE.

The price-cost margins of Table 3 suggest that there is no significant time variation in the magnitude of the computed mark-up for South African manufacturing industries.

\subsection{Firm-level (Worldscope) evidence from publicly listed companies}

In order to explore the degree of competition in South Africa we analyze firm-level data corresponding to listed firms in 60 countries in the period 1980-2004. We investigate a number of indicators of profitability across industries and over time. In order to make the analysis robust to influential outliers we truncate all the variables at the $5 \%$ level and report the median.

Results are reported in Table 4 through 6 .

INSERT TABLE 4, 5 AND 6 ABOUT HERE.

While listed firms in South Africa exhibit around 50\% higher profitability when this is measured with Net Income/Sales, Net Income/Assets,

\footnotetext{
${ }^{3}$ As outlined in section 3., an approach deriving from Hall (1990) proposes a more structured way of measuring markups that is based on Solow residuals. In the present section we favor our measure because Solow residuals are a noisy measure of markups (capturing all errors in the measurement of labor and capital), but also because our measure can be readily computed for a large number of countries, firms, industries, and years. Indeed, in the UNIDO database we do not have sufficient investment data for South African industries to be able to compute the capital stock.
} 
and Net Income Equity, their Gross-Margin, Market to Book Ratio, and Price-Earnings Ratios are markedly lower - see the results of Table 4 . These patterns do not show systematic variation in time - see the results of Table 5. These differences are in general statistically significant and robust to controlling for total and per capita GDP.

In Table 6 we report separately the median net income over sales ratio for those firms that have a size (based on sales) above and below the median within each industry-country-year cluster. In most sectors there is no significant difference between large and small firms neither in South Africa nor in the world as a whole - see the results reported in Table 6. In particular, there is no evidence that large firms in South Africa are relatively more profitable than small ones, at least in the corporate sector. The profitability of large firms until the mid-90s used to be around $10 \%$ lower than that of small firms. Since the late 1990s this pattern has reversed with particular strength in South Africa see Table 6. In the first half of the 2000s large firms in South Africa appear with ratios that are around $50 \%$ higher than those of small firms after controlling for what happened in the world. nor is there significant variation between large and small firms in the sample - see Table 6.

INSERT TABLE 7 ABOUT HERE.

Finally, we compare the aggregate industry price-cost margins in the manufacturing sector, as computed for the UNESCO industry data base with that of the listed firms in the Worldscope data set. Pricecost margin is defined as value added over output for the industry aggregates and as operating income over sales for listed firms. Results are reported in Table 7 . The ratio between the margins for listed firms and all firms is about twice as large in South Africa as in the world as a whole. The difference is observed across virtually all the sectors, although is especially large in Tobacco, Furniture and Electric Machinery. 


\subsection{Industry-level panel data results from the TIPS database}

In this section we explore both average manufacturing industry mark-ups, as well as industry level mark-ups in terms of the methodology outlined by section $3 .{ }^{4}$ For the average manufacturing sector mark-up we employ the pooled mean group dynamic heterogeneous panel estimation methodology of Pesaran, Shin and Smith (1999), ${ }^{5}$ thus controlling for both industry effects and dynamic adjustment to equilibrium over time. For individual sectors, estimation is by means of the cointegration-consistent ARDL methodology of section 8.0.2..

In Table 8 we report the PMGE results for the manufacturing sectors given by the specification:

$$
\begin{aligned}
N S R_{i t}= & \gamma_{0 i}+\gamma_{1} \text { ROEGER } R_{i t}+\varepsilon_{i t} \\
& \text { where ROEGER } R_{i t}=\alpha_{i t} \cdot[\Delta(w+l)-\Delta(r+k)]
\end{aligned}
$$

with $\alpha_{i t}$ denoting the share of labour in value-added of sector $i, \Delta(w+l)_{i t}$ the log change in nominal labour cost for sector $i, \Delta(r+k)_{i t}$ the log change in total capital stock for sector $i$, and $N S R_{i t}$ the nominal Solow residual. $\gamma_{1}$ now measures $(\mu-1)$, where $\mu=P / M C$ is the mark-up. ${ }^{6}$

INSERT TABLE 8 ABOUT HERE.

\footnotetext{
${ }^{4}$ We also computed the magnitude of the mark-up. Rearrangement of equation (14) gives:

$$
\mu-1=\frac{\Delta(p+q)-\alpha \Delta(w+l)-(1-\alpha) \Delta(r+k)}{\alpha[\Delta(w+l)-(r+k)]}
$$

allowing for ready computation of the mark-up. Given the noise, and other systematic components of the Solow residual, the series requires smoothing. We employed both moving average and Hodrick-Prescott filter smoothing, and split the full sample period into several overlapping ten-year sub-periods and calculate the average computed mark-up for each sub-period as a moving average. The general trend structure to emerge is broadly consistent with that reported for the estimated results, though they prove subject to greater volatility.

${ }^{5}$ See also the discussion in Fedderke (2004). The Estimation Methodology Appendix (section 8.) provides the detail.

${ }^{6}$ See the discussion in section 7 . for the derivation of this specification.
} 
Results are for the average manufacturing sector mark-up, both over the full sample period, as well as rolling decade-long sub-periods, estimated from the TIPS panel data set. Results indicate the presence of an aggregate mark-up for the manufacturing sector over the full sample period of $54 \%$. The error-correction term (the $\phi$-parameter), indicates that adjustment to the long-run equilibrium is rapid. The Hausman test statistic accepts the inference of an homogenous markup across all manufacturing sectors for the long run specification.

The declining trend in the aggregate manufacturing sector mark-up reported by Edwards and Van Tijl (2005) does not prove to be robust in our estimates - and appears to be drive largely by the relatively low estimate that emerges for the 1991-2000 sub-sample period. Both prior, and subsequent sample periods report higher mark-ups, suggesting that evidence of declining pricing power in the South African economy is not robust. More plausible is that the evidence is of a stable and non-declining level of pricing power, consistent with the firm-level evidence reported in section 4.2..

INSERT TABLE 9 ABOUT HERE.

For the sectoral evidence, we note that regressors are almost without exception stationary. Table 9 reports relevant ADF test statistics. ARDL remains an appropriate estimation strategy (with efficiency gains over OLS in the presence of dynamics). In Table 10 we report the individually estimated three digit manufacturing sector mark-up estimates obtained from the PSS ARDL cointegration estimations. ${ }^{7}$ Again, estimated mark-ups are reported both for the full sample period, as well as for rolling decade-long sub-periods.

INSERT TABLE 10 ABOUT HERE.

The mark-up is consistently statistically significant across all 3digit manufacturing sectors. ${ }^{8}$ Consistent with the aggregate evidence

\footnotetext{
${ }^{7}$ For details, see the explanation contained in the estimation methodology appendix, section 8.0.2..

${ }^{8}$ Standard errors and diagnostics for the full sample period estimation are consistently statistically sound with the exception of the Glass and Glass Products sector. Full results available from the authors on request.
} 
for the average mark-up in the manufacturing sector as a whole, the evidence suggests that mark-ups in manufacturing industry have increased rather than decreased toward the end of the sample period. In Table 11 we summarize by placing sectors into six main categories: high mark-ups that either decline, rise or stay the same into the last within-sample decade (1995-2004); or low mark-ups that either decline, rise or stay the same into the last within-sample decade (19952004). We find that for 16 sectors the mark-up increases, for seven it declines, while for four sectors there is little change.

INSERT TABLE 11 ABOUT HERE.

As a final consistency check of our results, given the potential for excessive volatility in the Solow residual, we computed the alternative measure of pricing power provided by the proxy for the Lerner index given by equation (3). Results are reported by three digit manufacturing sector, and by ten year sample sub-period in Table 12 . Consistent with the remainder of the results reported thus far, the results consistently indicate a non-declining pricing power in South African manufacturing industry. ${ }^{9}$

INSERT TABLE 12 ABOUT HERE.

\section{Market competition, productivity growth and employ- ment in SA}

The objective of this section is to explore the impact of the intensity of competition on productivity growth in the South African manufacturing sector. We find that pricing power in South African industry is associated with lower productivity growth, and with lower employment in South African manufacturing. Results prove to be robust across:

- Three distinct data sets, covering both industry level data as well as firm-level evidence.

\footnotetext{
${ }^{9}$ The sole exceptions are Printing, Plastics and Other transport equipment.
} 
- Two proxies of the Lerner index, given either by the differential between value added and the total wage bill as a proportion of output, or the difference between output and both wage and capital costs as a proportion of output.

\subsection{Competition and growth, using the industry-level (UNIDO) and firm-level (Worldscope) panel data}

We deal with the difference between average and marginal costs by estimating the relationship between growth and margins using the time variation in margins within each industry or sector. We estimate equation (1) such that:

$$
\text { Pgrowt }_{i t}=\alpha+\beta P C M 1_{i t-1}+I_{i}+I_{t}+\varepsilon_{i t},
$$

such that Pgrowth $_{i t}$ is given by average labor productivity growth in sector $i$ at time $t, P C M_{i t-1}$ is the lagged average mark-up in sector $i$, as computed in equation (2).

We present results referred to the world as a whole and to South Africa alone. In the world regressions we add the specification country indicators. The observations are not assumed to be independent within each country and year, so that we compute significance levels using errors that are clustered at the country and year level. If competition spurs innovation and growth, we would expect a negative coefficient for PCM.

This specification allows us to shield the results from either industry or firm characteristics that may affect measured price-cost margins but that are nonetheless not related to the degree of competition it faces. One such characteristic is the fact that the divergence between marginal and average costs may differ across industries due to differential economies of scale. Another possibility is that the exclusion of financial costs from the PCM measure may have a differential effect across industries sorted on capital intensity. If for some reason labor productivity growth is correlated with these characteristics, estimation using cross-industry data will suffer from omitted variable bias. 
However, as long as these characteristics do not vary systematically in time, the approach we propose solves the issue.

We also run firm-level regressions not controlling for firm fixed effects but only for industry fixed effects. In this case part of the variation comes from the difference of PCMs across firms and not only in time within firms.

Tables 13 and 14 present the basic results using industry and firmlevel data, respectively. In the first and fourth columns of Table 13 we use aggregates for the entire manufacturing sector. In the rest of the columns we use the variation of the 27 different manufacturing industries. Columns one through three correspond to the estimation over the data for the full set of 115 countries in the UNIDO data set, while the rest use data for South Africa alone.

INSERT TABLES 13 AND 14 ABOUT HERE.

The results very strongly suggest that there is a positive effect of product market competition on productivity growth. All the coefficients for margins are negative and statistically significant at conventional values. The economic magnitude of the effect is also very large. A $10 \%$ increase from the mean margin of 0.24 on the 115 -country sample implies a decrease in productivity growth of $2.4 \%$ per year. For the typical industry this would mean reducing growth from $2.6 \%$ a year to a mere $0.2 \%$. A similar change on margins in South Africa is associated with a decline of $1.6 \%$ per year, which would reduce the median growth from $1 \%$ to $-0.6 \%$.

Figures 1 and 2 depict graphically the relationship between margins and productivity found in the aggregate and the industry-level data. It is clear from these that the relationship is not driven by influential outliers but is a robust pattern in the data.

INSERT FIGURES 1 AND 2 ABOUT HERE.

Table 14 presents results with firm (columns one through three and seven through nine) and industry fixed effects (the rest of the columns) for a sample of 56 countries (left panel) and South Africa alone (right panel). As in the industry data, the coefficient for the $\mathrm{PCM}$ is in all cases negative and very significant in statistical terms, 
both on average across countries and in South Africa in particular. The economic magnitude of the effect is somewhat larger that what we found in the industry data. Here a $10 \%$ increase in margins (over the mean of 0.11 for the 56-country sample and 0.12 for South Africa) is associated with a decrease in productivity growth of $3.3 \%$ in the 56-country sample and $2.4 \%$ in South Africa. Again, these are very relevant magnitudes since the median productivity growth rate is $1.2 \%$ and $1.8 \%$ in each sample.

The results are virtually unchanged when we include the financial costs into cost (see columns 2, 5, 8, and 11).

Interestingly, the relationship between margins and productivity although negative on average, is U-shaped. These results are in line with Aghion et al (2005)'s theoretical predictions and extend their results for patenting activity by British publicly-listed firms.

INSERT TABLE 15 ABOUT HERE.

Even if we use lagged margins and control for industry and year fixed effects, the results above may still be due to spurious correlation. In particular, our computed margins may be caused to some extent by shocks to productivity growth. We attempt to control for this endogeneity by instrumenting margins with industry import penetration, which is assumed to affect productivity only through their effect on product market competition. Import penetration is computed for each industry, country, year observation as total imports over output. The raw data are taken from Mayer and Zignano (2005). Table 15 shows that import penetration is not a particularly good instrument for margins in the sense that its correlation with margins is typically not significantly negative. Not surprisingly, then, the second-stage IV estimates of the effect of margins on productivity growth are also typically not significantly negative. However, in the case that import penetration appears to be a good instrument (firm-level, all countries sample in column three) the IV estimate of the effect of margins -although smaller than before- enters negative and statistically significant. This suggests that at least part of the relation between margins and growth is caused by margins affecting growth and not the other 
way around.

We experimented with some other instruments such as the opening of the economy to trade, the degree of tradability of the industry, and the level of tariffs. In each case the results were similar to those reported in Table 15. The instruments are not particularly good, and the IV estimate of the coefficient of margins on growth typically enters negatively but not significantly so.

\subsection{Competition, growth and employment using the industry-level} panel data from the TIPS database

Given the discussion of section ??, we estimate equation (1) such that:

$$
\text { Pgrowth }_{i t}=\alpha+\beta P C M 2_{i t}+I_{i}+\varepsilon_{i t}
$$

where Pgrowth it $_{i t}$ is the Solow residual in sector $i$ at time $t, P C M 2$ is the proxy for the Lerner index as given by equation (3), and $I_{i}$ stands for industry fixed effects.

INSERT TABLE 16 ABOUT HERE.

Table 16 reports results both for the manufacturing industry average (under the PMGE coefficient), as well as for individual industries (under the MGE coefficients).

The Hausman test statistic confirms the inference of an homogenous mark-up across all manufacturing sectors for the long run specification. The error-correction term (the $\phi$-parameter), indicates that adjustment to the long-run equilibrium is rapid.

The PMGE coefficient of -0.10 coefficient means that on average across all manufacturing sectors, a 0.1 unit increase in LPROXY is associated with a $1 \%$ reduction in the real growth rate as measured by growth in total factor productivity. For individual industries, the general finding of a negative impact of the proxy for the industry specific Lerner index on sectoral productivity growth is confirmed.

We also explored the impact of competitive pressure on employment. Thus we estimated:

$$
L_{i t}=\alpha+\beta P C M 2_{i t}+I_{i}+\varepsilon_{i t}
$$


where $L_{i t}$ denotes employment in sector $i$ at time $t$, and PCM2 is the proxy for the Lerner index as given by equation (3).

INSERT TABLE 17 ABOUT HERE.

Table 17 reports results both for the manufacturing industry average (under the PMGE coefficient), as well as for individual industries (under the MGE coefficients).

Once again the Hausman test statistic confirms homogeneity across industry groups, though in the instance of employment adjustment to long run equilibrium, is relative slow (see the error-correction term given by the $\phi$-parameter).

The economic interpretation is that a 0.1 unit increase in LPROXY results in a reduction in employment of 3400 workers. For individual industries, the general finding of a negative impact of the industry specific Lerner index proxy on sectoral employment is confirmed.

\subsection{Labour flexibility}

As a final empirical contribution in this paper, we explore the link between industry mark-ups and the flexibility of labour markets.

The theory relating productivity residuals to the mark-up is based on a first-order Taylor approximation (in logs) of the primal and dual Solow residuals. This is appropriate when estimating the steady-state mark-up. However it does not allow for the investigation of cyclical effects which are second-order. An adaptation of a result derived by Oliviera Martins and Scarpetta (1999) shows us that under the condition of a two-input production function (we ignore intermediate inputs) and with Hicks neutrality in technical progress, the equation for the variable mark-up is given by:

$$
\begin{aligned}
\Delta \log \mu= & (\Delta q+\Delta p)-\Delta w+\left(\frac{1}{\sigma}-1\right) \bar{\mu}(1-\alpha) \Delta k \\
& -\frac{1}{\sigma} \frac{L}{L-\bar{L}} \bar{\mu}(1-\alpha) \Delta l-\bar{\mu} \alpha \Delta l
\end{aligned}
$$

where $\sigma$ denotes the elasticity of substitution between capital and 
labour, $\bar{\mu}$ the steady-state mark-up and $\bar{L}$ the amount of labour devoted to fixed costs.

The $\frac{L}{L-\bar{L}}$ term, representing the ratio of labour employed to the proportion of total labour employed which is variable, can be interpreted as an indicator of the degree of downward rigidities in adjustments of labour time. The feasible range is from unity (no rigidity) to infinity (complete rigidity).

Rearrangement of (7) provides the following expression:

$$
\begin{aligned}
L F & =\frac{1}{1-\alpha}\left(\frac{\Delta \log \mu-((\Delta q+\Delta p)-\Delta w)}{\bar{\mu}}-\alpha \Delta l\right) \\
& =\left(\frac{1}{\sigma}-1\right) \Delta k-\frac{1}{\sigma} \frac{L}{L-\bar{L}} \Delta l
\end{aligned}
$$

which leads to the specification that is estimated and discussed below.

In order to econometrically investigate the relationship between the mark-up and labour adjustment, equation (8) suggests a specification of the form:

$$
\begin{aligned}
y_{i t} & =\beta_{0 i}+\beta_{1} \Delta k_{i t}+\beta_{2} \Delta l_{i t}+\varepsilon_{i t} \\
\text { where } y_{i t} & =\frac{1}{1-\alpha_{i t}}\left(\frac{\Delta \log \mu_{i t}-\left((\Delta q+\Delta p)_{i t}-\Delta w_{i t}\right)}{\overline{\mu_{i}}}-\alpha_{i t} \Delta l_{i t}\right)
\end{aligned}
$$

under the now standard notation.

Two of the required variables are not available directly from the original panel data set: the steady-state mark-up and the growth rate of the mark-up. We use the mark-up that was estimated over the full sample period under the Hall-Roeger methodology in section 4.3. as the steady-state mark-up for each sector, and use the smoothed computed mark-up series to calculate the growth rate of the mark-up for each sector.

A simple manipulation of coefficient estimates allows us to obtain an estimate of the labour flexibility coefficient, $\frac{L}{L-\bar{L}}$. We use $\widehat{\beta_{1}}$ to obtain an estimate of the elasticity of substitution between capital and labour as in equation (10). Then we use $\widehat{\beta_{2}}$ along with the estimate 
of the elasticity of substitution to obtain an estimate of the labour adjustment coefficient as in equation (11).

$$
\begin{aligned}
& \widehat{\beta_{1}}=\left(\frac{1}{\widehat{\sigma}}-1\right) \Rightarrow \widehat{\sigma}=\frac{1}{\widehat{\beta_{1}}+1} \\
& \widehat{\beta_{2}}=\frac{1}{\widehat{\sigma}} \frac{\widehat{L}}{L-\bar{L}} \Rightarrow \frac{\widehat{L}}{L-\bar{L}}=\widehat{\sigma} \widehat{\beta_{2}}=\frac{\widehat{\beta_{2}}}{\widehat{\beta_{1}}+1}
\end{aligned}
$$

Under circumstances in which $\widehat{\beta_{1}}$ is not significantly different from zero, we infer an elasticity of substitution of unity in the calculation of the labour adjustment coefficient as this follows directly from $\widehat{\beta_{1}}=0$. Note that when we calculate the labour adjustment coefficient, the "correct" elasticity of substutition is defined to be $\widehat{\sigma}$ as in (11) if $\widehat{\beta_{1}}$ is significantly different from zero, and else as unity.

Recall that $\frac{L}{L-\bar{L}} \rightarrow 1$ implies perfect flexibility of the labour market, while $\frac{L}{L-\bar{L}} \rightarrow \infty$ implies inflexibility.

INSERT TABLE 18 ABOUT HERE.

We report the PMGE results for the manufacturing sector in Table 18. The error-correction term, the $\phi$-parameter, indicates that adjustment to the long-run equilibrium is rapid, and increasing with an increase in the adopted lag structure. The Hausman test accepts the inference of an homogenous labour adjustment coefficient across sectors for the long run.

Results indicate an estimate of an aggregate labour adjustment coefficient for the manufacturing sector over the full sample period of between 2.84 and 3.43, depending on which lag structure is adopted. This would suggest that of the total labour employed in manufacturing in South Africa, two-thirds is effectively allocated to fixed costs and only one-third is attributable to variable costs.

In order to investigate the trend of the aggregate manufacturing sector labour adjustment coefficient over time, we run the estimation of our specification on fifteen-year sub-periods and roll these through the full sample period year-by-year. The results are reported in Table 19. 
The general pattern that emerges is a decreasing labour adjustment coefficient through the first half of the sample followed by an increasing labour flexibility coefficient in the second half of the sample.

INSERT TABLE 19 ABOUT HERE.

The inference is thus of increasing flexibility in the adjustment of labour time in the first half of the sample, which is substantially reversed in the second half of the sample period.

\section{Conclusion}

In this paper we have explored three alternative panel data sets to first assess the degree of product market competition in South African manufacturing industries, and then to estimate the effect of product mkarket competition on growth and employment. Consistently across the three data set, we found that: (i) mark-ups remain significantly higher in SA industries than in corresponding industries worldwide; (ii) that a reduction in mark-ups (that is, an increase in product market competition) should have large positive effects on productivity growth and employment in South Africa.

The analysis in this paper can be extended in several interesting direction. A first extension is to push further on the search for good instruments for product market competition. A second extension is to look for entry data and perform the same kind of comparative analysis of entry measures and regression analysis of entry and growth as what we did for mark-ups in this paper. A third extension is to look at the service sector. These and other extensions of the paper shall await for further research. 


\section{Estimation of Mark-ups Methodology Appendix}

Under the assumption of constant returns to scale, the primal computation of the Solow Residual $(S R)$, or growth in Total Factor Productivity $(T F P)$, is related to the mark-up of prices over marginal cost. Hall (1990) demonstrates that:

$$
\begin{aligned}
\text { TFP } & =S R=\Delta q-\alpha \cdot \Delta l-(1-\alpha) \cdot \Delta k \\
& =(\mu-1) \cdot \alpha \cdot(\Delta l-\Delta k)+\theta
\end{aligned}
$$

where $\mu=P / M C$, with $P$ denoting price, and $M C$ denoting marginal cost. Under perfect competition $\mu=1$, while imperfectly competitive markets allow $\mu>1 . \Delta$ denotes the difference operator, lower case denotes the natural $\log$ transform, $q, l$, and $k$ denote real value-added, labour, and capital inputs, $\alpha$ is the labour share in value-added, and $\theta=\dot{A} / A$ denotes exogenous (Hicks-neutral) technological progress, where is $A$ is the technology parameter.

Estimation of equation (12) faces the difficulty that the explanatory variables $(\Delta l-\Delta k)$ will themselves be correlated with the productivity shocks $\theta$, and hence result in bias and inconsistency in estimates of $\mu$. One solution is to instrument. ${ }^{10}$ Unfortunately instrumentation for the US has led to the estimation of mark-ups that are generally implausibly high.

An alternative approach to avoid the endogeneity bias and instrumentation problems has been suggested by Roeger (1995). By computing the dual of the Solow Residual $(D S R)$, we can again obtain a

\footnotetext{
${ }^{10}$ This in turn raises the requirement that the instruments are correlated with the factor inputs, but not technological change and hence the error term $(\theta)$. In the case of applications to the US, instruments employed have been pure aggregate demand shifters. In particular, the variables employed have been aggregate real GDP, military expenditure, the world oil price, and the political party of the president. See for instance Hall (1990) and the discussion in Oliveira Martins and Scarpetta (1999).
} 
relation of the price-based productivity measure to the mark-up:

$$
\begin{aligned}
D S R & =\alpha \cdot \Delta w-(1-\alpha) \cdot \Delta r-\Delta p \\
& =(\mu-1) \cdot \alpha \cdot(\Delta w-\Delta r)+\theta
\end{aligned}
$$

with $w, r$ denoting the natural logs of the wage rate and rental price of capital respectively. While equation (13) is subject to the same endogeneity problems and hence instrumentation problems as equation (12), Roeger's insight was that subtraction of equation (13) from equation (12) would give us the nominal Solow residual (NSR), given by:

$$
\begin{aligned}
N S R & =\Delta(p+q)-\alpha \cdot \Delta(w+l)-(1-\alpha) \cdot \Delta(r+k) \\
& =(\mu-1) \cdot \alpha \cdot[\Delta(w+l)-\Delta(r+k)]
\end{aligned}
$$

in which the productivity shocks $(\theta)$ have cancelled out, removing the endogeneity problem, and hence the need for instrumentation. The mark-up is now accessible either to simple OLS estimation, or to direct computation.

Extensions of the framework for identifying the extent of mark-up pricing provided by equation (14), include relaxing the assumption of constant returns to scale, incorporating the impact of business cycles, import and export competition, market structure, and the use of alternative measures of output. Any estimate of mark-up that follows from Solow Residuals should be interpreted as lower-bound values if increasing returns to scale are present. ${ }^{11}$ Since tariff and other restrictions clearly carry implications for the degree of international competition to which domestic industry is exposed, and hence the magnitude of the feasible mark-up that domestic industry can maintain, import

\footnotetext{
${ }^{11}$ Specifically, one can show that where the assumption of constant returns to scale is dropped, equation (14) is actually:

$$
N S R=\left(\frac{\mu}{\lambda}-1\right) \cdot \alpha \cdot[\Delta(w+l)-\Delta(r+k)]
$$

where $\lambda>1$ denotes increasing returns to scale. Effectively equation (14) assumes $\lambda=1$. See Oliviera Martins and Scarpetta (1999).
} 
and export competition is relevant to the pricing power of industry. ${ }^{12}$ Market structure similarly carries implications for competitive pressure and hence pricing behaviour in markets. ${ }^{13}$ Finally, both cyclical fluctuations and the use of gross output accounting for intermediate inpus, or value added in the absence of intermediate inputs carries implications for the magnitude of the mark-up. ${ }^{14}$

\section{Estimation Methodology Appendix}

\subsubsection{The Panel Estimator: Pooled Mean Group Estimator}

Consider the unrestricted error correction $\operatorname{ARDL}(p, q)$ representation:

$$
\Delta y_{i t}=\phi_{i} y_{i, t-1}+\boldsymbol{\beta}_{i}^{\prime} \mathbf{x}_{i, t-1}+\sum_{j=1}^{p-1} \lambda_{i j} \Delta y_{i, t-j}+\sum_{j=0}^{q-1} \boldsymbol{\delta}_{i j}^{\prime} \Delta \mathbf{x}_{i, t-j}+\mu_{i}+\varepsilon_{i t},(15)
$$

where $i=1,2, \ldots, N, t=1,2, \ldots, T$, denote the cross section units and time periods respectively. Here $y_{i t}$ is a scalar dependent variable, $\mathbf{x}_{i t}$ $(k \times 1)$ a vector of (weakly exogenous) regressors for group $i$, and $\mu_{i}$ represents fixed effects. Allow the disturbances $\varepsilon_{i t}$ 's to be independently distributed across $i$ and $t$, with zero means and variances $\sigma_{i}^{2}$ $>0$, and assume that $\phi_{i}<0$ for all $i$. Then there exists a long-run relationship between $y_{i t}$ and $\mathbf{x}_{i t}$ :

$$
y_{i t}=\boldsymbol{\theta}_{i}^{\prime} \mathbf{x}_{i t}+\eta_{i t}, i=1,2, \ldots, N, t=1,2, \ldots, T,
$$

where $\boldsymbol{\theta}_{i}=-\boldsymbol{\beta}_{i}^{\prime} / \phi_{i}$ is the $k \times 1$ vector of the long-run coefficients, and $\eta_{i t}$ 's are stationary with possibly non-zero means (including fixed effects). This allows equation (15) to be written as:

$$
\Delta y_{i t}=\phi_{i} \eta_{i, t-1}+\sum_{j=1}^{p-1} \lambda_{i j} \Delta y_{i, t-j}+\sum_{j=0}^{q-1} \boldsymbol{\delta}_{i j}^{\prime} \Delta \mathbf{x}_{i, t-j}+\mu_{i}+\varepsilon_{i t},
$$

\footnotetext{
${ }^{12}$ See the discussion in Hakura (1998), and the extensions and empirical application in Fedderke, Kularatne and Mariotti (2006).

${ }^{13}$ See the discussion in Fedderke, Kularatne and Mariotti (2006).

${ }^{14}$ See Oliviera Martins and Scarpetta (1999).
} 
where $\eta_{i, t-1}$ is the error correction term given by equation (16), and thus $\phi_{i}$ is the error correction coefficient measuring the speed of adjustment towards the long-run equilibrium.

This general framework allows the formulation of the PMGE, which allows the intercepts, short-run coefficients and error variances to differ freely across groups, but the long-run coefficients to be homogenous; i.e. $\boldsymbol{\theta}_{i}=\boldsymbol{\theta} \forall i$. Group-specific short-run coefficients and the common long-run coefficients are computed by the pooled maximum likelihood estimation. Denoting these estimators by $\tilde{\phi}_{i}, \tilde{\boldsymbol{\beta}}_{i}$, $\tilde{\lambda}_{i j}, \tilde{\boldsymbol{\delta}}_{i j}$ and $\tilde{\boldsymbol{\theta}}$, we obtain the PMG estimators by $\hat{\phi}_{P M G}=\frac{\sum_{i=1}^{N} \tilde{\phi}_{i}}{N}$, $\hat{\boldsymbol{\beta}}_{P M G}=\frac{\sum_{i=1}^{N} \tilde{\boldsymbol{\beta}}_{i}}{N}, \hat{\lambda}_{j P M G}=\frac{\sum_{i=1}^{N} \tilde{\lambda}_{i j}}{N}, j=1, \ldots, p-1$, and $\hat{\boldsymbol{\delta}}_{j P M G}=$ $\frac{\sum_{i=1}^{N} \tilde{\boldsymbol{\delta}}_{i j}}{N}, j=0, \ldots, q-1, \hat{\boldsymbol{\theta}}_{P M G}=\tilde{\boldsymbol{\theta}}$.

PMGE provides an intermediate case between the dynamic fixed effects (DFE) estimator which imposes the homogeneity assumption for all parameters except for the fixed effects, and the mean group estimator (MGE) proposed by Pesaran and Smith (1995), which allows for heterogeneity of all parameters. It exploits the statistical power offered by the panel through long-run homogeneity, while still admitting short-run heterogeneity.

The crucial question is whether the assumption of long-run homogeneity is justified, given the threat of inefficiency and inconsistency noted by Pesaran and Smith (1995). We employ a Hausman (1978) test (hereafter $h$ test) on the difference between MG and PMG estimates of long-run coefficients to test for long run heterogeneity. ${ }^{15}$ Note that as long as the homogeneity Hausman test is passed in our estimations, we report only PMG estimation results. ${ }^{16}$

Finally, it is worth pointing out that a crucial advantage of the estimation approach of the present paper, is that the dynamics of

\footnotetext{
${ }^{15}$ An alternative is offered by Log-Likelihood Ratio tests. However, the finite sample performance of such tests are generally unknown and thus unreliable. We therefore employ the h-test instead.

${ }^{16}$ The authors thank Yongcheol Shin for the provision of the appropriate GAUSS code for estimation purposes.
} 
adjustment in the mark-up are explicitly modelled, while recognizing the presence of a long run equilibrium relationship underlying the dynamics. Thus the justification for the use of the PMG estimator is that it is consistent both with the underlying theory of a homogenous long-run mark-up of price over marginal cost relationship and the possibly heterogeneous dynamic time series nature of the data. As long as sector-homogeneity is assured, the PMGE offers efficiency gains over the MGE, while granting the possibility of dynamic heterogeneity across sectors unlike the DFE estimator. In the presence of long run homogeneity, therefore, our preference is for the use of the PMGE.

\subsubsection{The ARDL Approach to Cointegration}

Pesaran, Shin and Smith (1996, 2001) (hereafter PSS) advocate the use of autoregressive distributed lag models for the estimation of long run relations. ${ }^{17}$ The PSS bounds testing approach proceeds by estimating the error correction model given by:

$$
y_{t}=\alpha_{0}+\sum_{i=1}^{p} \beta_{i} \Delta y_{t-i}+\sum_{j=1}^{k} \sum_{i=1}^{p} \gamma_{j i} \Delta x_{j, t-i}+\left(\delta_{1} y_{t-1}+\sum_{j=1}^{k} \delta_{j+1} x_{j}\right)
$$

Tests of significance of joint zero restrictions on the $\delta^{\prime} s$ of the error correction model establish the presence of a long run relationship, and its directionality. Confirmation of a unique long run relationship allows for estimation in a two step strategy, selecting the ARDL orders on the basis of the Akaike Information criterion (AIC), then estimating the long and short run coefficients on the basis of the selected model. Estimation of the long run relationship $y_{t}=\zeta+\eta t+\theta x_{t}+\nu_{t}$ can be shown to be feasible on the basis of the "Bewley regression:"

$$
y_{t}=\zeta+\eta t+\sum_{i=1}^{k} \theta_{i} x_{i}+\sum_{j=0}^{p-1} \gamma_{j} \Delta y_{t-j}+\sum_{m=0}^{q-1} \delta_{m} \Delta x_{t-m}
$$

\footnotetext{
${ }^{17}$ See also the discussion in Pesaran (1997).
} 
by the instrumental variables method, where $1, t, \sum_{i=1}^{k} x_{i}, \sum_{j=0}^{p-1} \Delta y_{t-j}$, $\sum_{m=0}^{q-1} \Delta x_{t-m}$, serve as instruments, ${ }^{18}$

\footnotetext{
${ }^{18}$ The mthodology outlined presumes that the $x_{i}$ and $\epsilon$ are uncorrelated. Where they are correlated, the methodology remains valid, but the "Bewley regression" requires augmentation.
} 


\section{References}

Aghion, P., Bloom, N., Blundell, R., Griffith, R., and Howitt, P., 2005, Competition and Innovation: An Inverted-U Relationship, Quarterly Journal of Economics, 120(2), 701-728.

Blundell, R., Griffith, R. and J. Van Reenen (1995), "Dynamic Count Data Models of Technological Innovation", Economic Journal, Vol. 105, March 1995, 333-344

Blundell, R., Griffith, R. and J. Van Reenen (1999), "Market Share, Market Value and Innovation in a Panel of British Manufacturing Firms", Review of Economic Studies, vol. 66, 529-554.

Fedderke, J.W., 2004, Investment in Fixed Capital Stock: testing for the impact of sectoral and systemic uncertainty, Oxford Bulletin of Economics and Statistics, 66(2), 165-87.

Fedderke J.W., Kularatne, C., and Mariotti, M., 2006, Mark-up Pricing in South African Industry, Journal of African Economies, forthcoming.

Hakura, D.S., 1998, The Effects of European Economic Integration on the Profitability of Industry, International Monetary Fund Working Paper WP/98/85.

Hall, R.E., 1988, The Relation between Price and Marginal Cost in US Industry, Journal of Political Economy, 96(5), 921-47.

Hall, R.E., 1990, The Invariance Properties of Solow's Productivity Residual, in P. Diamond (Ed..) Growth, Productivity, Unemployment, Cambridge MA: MIT Press.

Hausman, J.A., 1978, Specification tests in economics, Econometrica, $46,1251-70$.

Nickell, S. (1996) "Competition and Corporate Performance", Journal of Political Economy, 104:4, 724-746 
Oliveira Martins, J., and Scarpetta, S., 1999, The Levels and Cyclical Behaviour of Mark-ups Across Countries and Market Structures, OECD Economics Department Working Papers No. 213.

Pesaran, M.H., 1997, The Role of Economic Theory in Modelling the Long Run, Economic Journal, 107, 178-91.

Pesaran, M.H. and Smith, R., 1995, Estimating Long-Run Relationships from Dynamic Heterogeneous Panels, Journal of Econometrics, Vol. 68, pp. 79-113.

Pesaran, M.H., Shin, Y. and Smith, R.J., 1996, Testing for the existence of a long run relationship, DAE Working Paper No.9622, Department of Applied Economics, University of Cambridge.

Pesaran, M.H., Shin, Y. and Smith, R., 1999, Pooled Mean Group Estimation of Dynamic Heterogeneous Panels, Journal of the American Statistical Association, Vol. 94, pp. 621-634.

Pesaran, M.H., Shin, Y., and Smith, R.P., 2001, Bounds testing approaches to the analysis to the testing of level relationships, Journal of Applied Econometrics, 16, 289-326.

Roeger, W., 1995, Can Imperfect Competition explain the Difference between Primal and Dual Productivity Measures? Estimates for US Manufacturing, Journal of Political Economy, 103, 316-30. 


\begin{tabular}{|l|l|}
\hline Table 1: Three Digit Manufacturing Sectors Included in Study \\
\hline Food & Rubber products \\
Beverages & Glass \& glass products \\
Tobacco & Non-metallic minerals \\
Textiles & Basic iron \& steel \\
Wearing apparel & Basic non-ferrous metals \\
Leather \& leather products & Metal products excluding machinery \\
Footwear & Machinery \& equipment \\
Wood \& wood products & Electrical machinery \\
Paper \& paper products & Television \& other communications equipment \\
Printing, publishing \& recorded media & Professional equipment \\
Coke \& refined petroleum products & Motor vehicles, parts \& accessories \\
Basic chemicals & Other transport equipment \\
Other chemicals & Furniture \\
Plastic products & Other manufacturing industry \\
\hline
\end{tabular}

\begin{tabular}{|l|c|c|c|c|c|c|}
\hline \multicolumn{7}{|c|}{ Table 2: Standard deviations of computed mark-ups } \\
\hline & $\mathbf{1 9 7 1 -}$ & $\mathbf{1 9 7 5 -}$ & $\mathbf{1 9 8 1 -}$ & $\mathbf{1 9 8 5}-$ & $\mathbf{1 9 9 1 -}$ & $\mathbf{1 9 9 5 -}$ \\
\hline & $\mathbf{1 9 8 0}$ & $\mathbf{1 9 8 4}$ & $\mathbf{1 9 9 0}$ & $\mathbf{1 9 9 4}$ & $\mathbf{2 0 0 0}$ & $\mathbf{2 0 0 4}$ \\
\hline Food & 0.54 & 0.23 & 0.14 & 0.13 & $1.26 \#$ & $1.30 \#$ \\
\hline Beverages & 5.00 & 3.70 & 1.68 & 1.63 & 1.00 & 3.52 \\
\hline Tobacco & 10.64 & 8.31 & 8.22 & 14.16 & 19.92 & $259.31 \#$ \\
\hline Textiles & 1.91 & 0.21 & 0.52 & 0.50 & $1.37 \#$ & $2.39 \#$ \\
\hline Wearing apparel & 0.18 & 0.10 & 0.29 & 0.27 & $9.49 \#$ & $9.67 \#$ \\
\hline Leather \& leather products & 0.08 & 0.09 & 0.10 & 0.11 & $1.47 \#$ & $3.42 \#$ \\
\hline Footwear & 0.06 & 0.04 & 0.12 & 0.15 & $3.40 \#$ & $3.85 \#$ \\
\hline Wood \& wood products & 0.67 & 0.41 & 0.64 & 0.62 & $1.99 \#$ & $1.95 \#$ \\
\hline Paper \& paper products & 0.51 & 0.39 & 11.34 & 11.33 & 4.04 & 4.30 \\
\hline Printing, publishing \& recorded media & 0.20 & 0.09 & 0.63 & 0.60 & $2.20 \#$ & $2.15 \#$ \\
\hline Coke \& refined petroleum & 11.47 & 2.74 & 7.31 & 8.39 & $44.10 \#$ & $42.85 \#$ \\
\hline Basic chemicals & 1.38 & 0.45 & 0.41 & 0.36 & $2.04 \#$ & $3.57 \#$ \\
\hline Other chemicals \& man-made fibers & 0.63 & 0.28 & 0.61 & 0.59 & $1.78 \#$ & $8.69 \#$ \\
\hline Rubber products & 0.29 & 0.13 & 0.23 & 0.24 & $2.41 \#$ & $6555.49 \#$ \\
\hline Plastic products & 0.83 & 0.71 & 5.01 & 5.00 & 1.28 & 4.00 \\
\hline Glass \& glass products & 0.16 & 0.11 & 0.49 & 0.49 & 0.76 & $7.70 \#$ \\
\hline Non-metallic minerals & 0.54 & 0.29 & 4.25 & 4.23 & 3.71 & 4.39 \\
\hline Basic iron \& steel & 1.01 & 0.22 & 0.14 & 0.12 & $1.44 \#$ & $6.33 \#$ \\
\hline Basic non-ferrous metals & 1.10 & 0.63 & 0.97 & 0.94 & $13.78 \#$ & $18.53 \#$ \\
\hline Metal products excluding machinery & 0.21 & 0.14 & 0.65 & 1.22 & 1.19 & $2.33 \#$ \\
\hline Machinery \& equipment & 0.69 & 0.26 & 0.43 & 0.41 & $1.96 \#$ & $2.10 \#$ \\
\hline Electrical machinery \& apparatus & n/a & n/a & n/a & n/a & n/a & n/a \\
\hline Television, \& communications equipment & 0.53 & 0.47 & 7.79 & 8.70 & 9.44 & 8.53 \\
\hline Professional \& scientific equipment & 0.96 & 0.93 & 0.39 & 0.91 & $2.05 \#$ & $4.76 \#$ \\
\hline Motor vehicles, parts \& accessories & 0.20 & 0.17 & 2.21 & 2.24 & $19.30 \#$ & $20.27 \#$ \\
\hline Other transport equipment & 2.39 & 1.12 & 1.05 & 1.35 & $5.56 \#$ & $5.76 \#$ \\
\hline Furniture & 0.55 & 0.54 & 0.31 & 0.32 & $1.61 \#$ & $1.67 \#$ \\
\hline Other manufacturing & 1.97 & 1.94 & 1.74 & 1.92 & 1.89 & $2.95 \#$ \\
\hline
\end{tabular}


Table 3: South African UNIDO Industry Data: Price-Cost Margins and Labor Productivity Growth

\begin{tabular}{|c|c|c|c|c|c|c|c|c|c|c|}
\hline \multirow[t]{2}{*}{ Industry } & \multicolumn{2}{|c|}{$1976-80$} & \multicolumn{2}{|c|}{ 1981-85 } & \multicolumn{2}{|c|}{$19886-90$} & \multicolumn{2}{|c|}{ 1991-95 } & \multicolumn{2}{|c|}{ 1996-2000 } \\
\hline & PC Margin & Prod Growth & C Margin & Prod Growth & C Margin & Prod Growth & PC Margin & Prod Growth & PC Margin & Prod Growth \\
\hline Beverages & 0.359 & 0.0075 & 0.364 & 0.0263 & 0.373 & 0.0700 & 0.377 & 0.0656 & 0.361 & 0.0487 \\
\hline Fabricated metal products & 0.222 & 0.0062 & 0.211 & 0.0084 & 0.212 & 0.0348 & 0.216 & 0.0256 & 0.215 & 0.0318 \\
\hline Food products & 0.170 & -0.0048 & 0.167 & 0.0090 & 0.180 & 0.0439 & 0.190 & 0.0534 & 0.182 & 0.0223 \\
\hline Footwear, except rubber or plastic & 0.234 & 0.0210 & 0.216 & 0.0104 & 0.192 & 0.0341 & 0.197 & -0.0139 & 0.186 & 0.0303 \\
\hline Furniture, except metal & 0.228 & 0.0229 & 0.212 & 0.0021 & 0.216 & 0.0232 & 0.210 & 0.0398 & 0.206 & 0.0528 \\
\hline Glass and products & 0.275 & 0.0452 & 0.265 & 0.0168 & 0.285 & 0.0393 & 0.300 & 0.0646 & 0.290 & 0.0423 \\
\hline Industrial chemicals & 0.255 & -0.0049 & 0.231 & 0.0288 & 0.255 & 0.0454 & 0.250 & 0.0597 & 0.255 & 0.0214 \\
\hline Iron and steel & 0.189 & 0.0372 & 0.186 & 0.0267 & 0.214 & 0.0577 & 0.219 & 0.0345 & 0.193 & 0.0047 \\
\hline Leather products & 0.204 & 0.0093 & 0.197 & 0.0134 & 0.180 & 0.0322 & 0.189 & 0.0326 & 0.159 & 0.0128 \\
\hline Machinery, electric & 0.230 & 0.0133 & 0.239 & 0.0339 & 0.236 & 0.0523 & 0.240 & 0.0457 & 0.230 & 0.0615 \\
\hline Machinery, except electrical & 0.233 & 0.0148 & 0.226 & 0.0148 & 0.223 & 0.0457 & 0.235 & 0.0563 & 0.209 & 0.0214 \\
\hline Misc. petroleum and coal products & 0.209 & 0.0388 & 0.196 & -0.0136 & 0.222 & 0.0422 & 0.231 & 0.0629 & 0.204 & 0.0241 \\
\hline Non-ferrous metals & 0.198 & 0.0283 & 0.188 & 0.0047 & 0.200 & 0.0570 & 0.198 & 0.0612 & 0.182 & 0.0027 \\
\hline Other chemicals & 0.256 & 0.0174 & 0.259 & 0.0265 & 0.259 & 0.0454 & 0.275 & 0.0489 & 0.285 & 0.0401 \\
\hline Other manufactured products & 0.266 & 0.0244 & 0.244 & -0.0005 & 0.227 & 0.0024 & 0.223 & 0.0271 & 0.239 & 0.0487 \\
\hline Other non-metallic mineral products & 0.277 & 0.0306 & 0.266 & 0.0172 & 0.284 & 0.0561 & 0.285 & 0.0339 & 0.282 & 0.0334 \\
\hline Paper and products & 0.226 & 0.0229 & 0.206 & 0.0156 & 0.215 & 0.0697 & 0.222 & 0.0591 & 0.217 & 0.0107 \\
\hline Petroleum refineries & 0.191 & 0.0289 & 0.168 & -0.0233 & 0.239 & 0.0725 & 0.272 & 0.0158 & 0.237 & 0.0240 \\
\hline Plastic products & 0.246 & 0.0115 & 0.236 & 0.0203 & 0.237 & 0.0495 & 0.237 & 0.0515 & 0.230 & 0.0350 \\
\hline Pottery, china, earthenware & 0.300 & 0.0201 & 0.278 & 0.0054 & 0.293 & 0.0482 & 0.284 & 0.0365 & 0.295 & 0.0205 \\
\hline Printing and publishing & 0.265 & 0.0187 & 0.244 & 0.0047 & 0.246 & 0.0470 & 0.254 & 0.0668 & 0.244 & 0.0513 \\
\hline Professional \& scientific equipment & 0.269 & 0.0086 & 0.266 & 0.0350 & 0.268 & 0.0577 & 0.257 & -0.0041 & 0.250 & 0.0433 \\
\hline Rubber products & 0.224 & 0.0327 & 0.233 & 0.0168 & 0.231 & 0.0257 & 0.237 & 0.0741 & 0.239 & 0.0203 \\
\hline Textiles & 0.213 & 0.0141 & 0.204 & 0.0097 & 0.211 & 0.0395 & 0.225 & 0.0411 & 0.202 & 0.0244 \\
\hline Tobacco & 0.396 & 0.0058 & 0.426 & 0.0477 & 0.464 & 0.0823 & 0.478 & 0.0329 & 0.419 & 0.0691 \\
\hline Transport equipment & 0.198 & 0.0156 & 0.189 & 0.0193 & 0.190 & 0.0430 & 0.192 & 0.0932 & 0.189 & 0.0678 \\
\hline Wearing apparel, except footwear & 0.205 & 0.0175 & 0.197 & -0.0010 & 0.182 & 0.0286 & 0.206 & 0.0215 & 0.207 & 0.0226 \\
\hline Wood products, except furniture & 0.233 & 0.0298 & 0.214 & -0.0042 & 0.213 & 0.0456 & 0.223 & 0.0526 & 0.213 & 0.0197 \\
\hline Total manufacturing & 0.224 & 0.0198 & 0.212 & 0.0155 & 0.231 & 0.0437 & 0.242 & 0.0449 & 0.233 & 0.0445 \\
\hline
\end{tabular}


Table 4: Firm Level (Worldscope) Evidence on Profitability: The Level of Profitability Employing Alternative Measures of Firm Profitability by Three Digit Manufacturing Industry

APPAREL
AUTOMOTIVE
BEVERAGES
CHEMICALS
CONSTRUCTION
DIVERSIFIED
DRUGS, COSMETICS \& HEALTH CARE
ELECTRICAL
ELECTRONICS
FINANCIAL
FOOD
MACHINERY \& EQUIPMENT
METAL PRODUCERS
METAL PRODUCT MANUFACTURERS
MISCELLANEOUS
OIL, GAS, COAL \& RELATED SERVICES
PAPER
PRINTING \& PUBLISHING
RECREATION
RETAILERS
TEXTILES
TOBACCO
TRANSPORTATION
UTILITIES
AVEIAGE

\begin{tabular}{|c|c|c|c|c|c|c|c|c|c|c|c|c|c|c|}
\hline \multicolumn{2}{|c|}{ Net Income/Sales } & \multicolumn{4}{|c|}{ Net Income/Assets } & \multicolumn{2}{|c|}{ Net Income/Equity } & \multicolumn{3}{|c|}{ Gross Margin } & \multicolumn{4}{|c|}{ Market to Book Assets } \\
\hline ZAF & World & Diff & ZAF & World & Diff & ZAF & World & Diff & ZAF & World & Diff & ZAF & World & \\
\hline 0.036 & 0.032 & 0.004 & 0.056 & 0.037 & 0.020 & 0.099 & 0.090 & 0.009 & 0.131 & 0.288 & -0.157 & 0.84 & 1.11 & \\
\hline 0.032 & 0.021 & 0.011 & 0.054 & 0.024 & 0.029 & 0.113 & 0.076 & 0.037 & 0.096 & 0.196 & -0.099 & 0.79 & 1.10 & \\
\hline 0.063 & 0.046 & 0.017 & 0.078 & 0.041 & 0.037 & 0.148 & 0.094 & 0.053 & 0.189 & 0.392 & -0.203 & 1.15 & 1.31 & \\
\hline 0.070 & 0.032 & 0.038 & 0.080 & 0.029 & 0.051 & 0.172 & 0.080 & 0.092 & 0.244 & 0.274 & -0.029 & 1.24 & 1.18 & \\
\hline 0.035 & 0.023 & 0.012 & 0.043 & 0.022 & 0.021 & 0.116 & 0.075 & 0.042 & 0.214 & 0.192 & 0.022 & 0.93 & 1.07 & \\
\hline 0.040 & 0.031 & 0.009 & 0.057 & 0.026 & 0.032 & 0.159 & 0.086 & 0.073 & 0.110 & 0.254 & -0.144 & 1.01 & 1.11 & \\
\hline 0.080 & 0.046 & 0.034 & 0.046 & 0.027 & 0.019 & 0.169 & 0.073 & 0.097 & 0.276 & 0.520 & -0.245 & 1.85 & 2.10 & \\
\hline 0.041 & 0.029 & 0.012 & 0.071 & 0.029 & 0.042 & 0.158 & 0.078 & 0.080 & 0.155 & 0.264 & -0.109 & 1.21 & 1.24 & \\
\hline 0.043 & 0.028 & 0.015 & 0.053 & 0.024 & 0.029 & 0.183 & 0.069 & 0.113 & 0.154 & 0.370 & -0.217 & 1.32 & 1.58 & \\
\hline 0.060 & 0.078 & -0.017 & 0.028 & 0.010 & 0.018 & 0.130 & 0.084 & 0.045 & 0.577 & 0.472 & 0.105 & 1.05 & 1.02 & \\
\hline 0.037 & 0.025 & 0.013 & 0.059 & 0.032 & 0.026 & 0.146 & 0.082 & 0.064 & 0.126 & 0.245 & -0.119 & 1.07 & 1.16 & \\
\hline 0.027 & 0.025 & 0.002 & 0.059 & 0.024 & 0.035 & 0.176 & 0.070 & 0.105 & 0.110 & 0.263 & -0.153 & 1.06 & 1.19 & \\
\hline 0.128 & 0.028 & 0.101 & 0.053 & 0.012 & 0.042 & 0.123 & 0.039 & 0.084 & 0.242 & 0.220 & 0.022 & 1.22 & 1.12 & \\
\hline 0.034 & 0.024 & 0.010 & 0.052 & 0.025 & 0.027 & 0.131 & 0.068 & 0.063 & 0.093 & 0.215 & -0.122 & 0.83 & 1.09 & \\
\hline 0.040 & 0.023 & 0.017 & 0.052 & 0.026 & 0.026 & 0.151 & 0.076 & 0.076 & 0.179 & 0.285 & -0.106 & 1.18 & 1.28 & \\
\hline 0.056 & 0.041 & 0.015 & 0.051 & 0.025 & 0.026 & 0.129 & 0.070 & 0.059 & 0.250 & 0.383 & -0.133 & 1.04 & 1.24 & \\
\hline 0.056 & 0.028 & 0.028 & 0.066 & 0.025 & 0.041 & 0.172 & 0.075 & 0.097 & 0.149 & 0.240 & -0.091 & 1.17 & 1.07 & \\
\hline 0.075 & 0.048 & 0.027 & 0.074 & 0.045 & 0.029 & 0.154 & 0.114 & 0.040 & 0.142 & 0.355 & -0.213 & 1.49 & 1.44 & \\
\hline 0.068 & 0.032 & 0.035 & 0.047 & 0.027 & 0.021 & 0.138 & 0.071 & 0.067 & 0.301 & 0.395 & -0.093 & 1.21 & 1.34 & \\
\hline 0.028 & 0.018 & 0.011 & 0.065 & 0.033 & 0.032 & 0.181 & 0.093 & 0.088 & 0.151 & 0.272 & -0.121 & 1.17 & 1.21 & \\
\hline 0.048 & 0.022 & 0.026 & 0.060 & 0.020 & 0.039 & 0.112 & 0.060 & 0.052 & 0.127 & 0.219 & -0.091 & 0.90 & 1.01 & \\
\hline 0.051 & 0.073 & -0.023 & 0.090 & 0.059 & 0.031 & 0.175 & 0.183 & -0.009 & 0.121 & 0.278 & -0.158 & 0.86 & 1.45 & \\
\hline 0.049 & 0.024 & 0.025 & 0.066 & 0.022 & 0.045 & 0.159 & 0.072 & 0.087 & 0.187 & 0.239 & -0.051 & 1.17 & 1.10 & \\
\hline 0.057 & 0.064 & -0.007 & 0.047 & 0.033 & 0.015 & 0.134 & 0.108 & 0.026 & 0.264 & 0.423 & -0.159 & 1.42 & 1.14 & \\
\hline 0.052 & 0.035 & 0.017 & 0.059 & 0.028 & 0.030 & 0.147 & 0.083 & 0.064 & 0.191 & 0.302 & -0.111 & 1.13 & 1.24 & \\
\hline
\end{tabular}

Price/Earnings Ratio ZAF World Diff $\begin{array}{lll}5.81 & 9.57 & -3.76 \\ 6.59 & 11.55 & -4.96\end{array}$ $\begin{array}{lll}9.63 & 15.46 & -5.83 \\ 8.07 & 13.24 & -5.17\end{array}$ $\begin{array}{lll}8.07 & 13.24 & -5.17\end{array}$ $\begin{array}{lll}8.79 & 11.39 & -4.61 \\ 8.63 & 12.27 & -3.64\end{array}$ $\begin{array}{lll}8.63 & 12.27 & -3.64 \\ 11.60 & 10.41 & 1.19\end{array}$ $\begin{array}{lll}10.14 & 12.16 & -2.01\end{array}$ $\begin{array}{lll}8.29 & 11.07 & -2.78 \\ 8.77 & 12.48 & -3.71\end{array}$ $\begin{array}{lll}8.77 & 12.48 & -3.71 \\ 7.70 & 13.34 & -5.64\end{array}$ $\begin{array}{lll}6.31 & 12.69 & -6.38\end{array}$ $\begin{array}{lll}8.86 & 6.52 & 2.33\end{array}$ $\begin{array}{lll}6.63 & 11.69 & -5.06\end{array}$ $\begin{array}{lll}6.53 & 11.51 & -4.99\end{array}$ $\begin{array}{lll}6.12 & 10.47 & -4.35\end{array}$ $\begin{array}{lll}8.65 & 11.24 & -2.59\end{array}$ $\begin{array}{lll}8.61 & 14.12 & -5.51 \\ 7.67 & 12.44 & -4.77\end{array}$ $\begin{array}{lll}8.67 & 12.44 & -4.77 \\ 9.04 & 13.58 & -4.54\end{array}$ $\begin{array}{lll}9.23 & 8.85- & -2.63\end{array}$ $\begin{array}{lll}5.57 & 11.18 & -5.61\end{array}$ $\begin{array}{lll}7.87 & 11.88 & -4.01 \\ 11.89 & 11.22 & 0.67\end{array}$ 
Table 5: Firm Level (Worldscope) Evidence on Profitability: The Level of Profitability - Variation Across Time

\begin{tabular}{|c|c|c|c|c|c|c|c|c|c|c|c|c|c|c|c|c|c|c|}
\hline \multicolumn{3}{|c|}{ Net Income/Sales } & \multicolumn{4}{|c|}{ Net Income/Assets } & \multicolumn{2}{|c|}{ Net Income/Equity } & \multicolumn{3}{|c|}{ Gross Margin } & \multicolumn{4}{|c|}{ Market to Book Assets } & \multicolumn{3}{|c|}{ Price/Earnings Ratio } \\
\hline & ZAF & World & Diff & ZAF & World & Diff & ZAF & World & Diff & ZAF & World & Diff & ZAF & World & Diff & ZAF & World & Diff \\
\hline 1980 & 0.063 & 0.038 & 0.025 & 0.074 & 0.037 & 0.037 & 0.210 & 0.128 & 0.082 & 0.821 & 0.254 & 0.568 & 1.20 & 1.01 & 0.19 & 6.45 & 8.42 & -1.97 \\
\hline 1981 & 0.062 & 0.035 & 0.027 & 0.079 & 0.035 & 0.044 & 0.239 & 0.123 & 0.116 & 0.811 & 0.253 & 0.558 & 1.10 & 1.00 & 0.10 & 5.54 & 8.33 & -2.79 \\
\hline 1982 & 0.059 & 0.030 & 0.029 & 0.070 & 0.028 & 0.042 & 0.185 & 0.104 & 0.081 & 0.514 & 0.258 & 0.256 & 0.98 & 1.02 & -0.04 & 5.51 & 10.23 & -4.72 \\
\hline 1983 & 0.047 & 0.031 & 0.016 & 0.049 & 0.029 & 0.020 & 0.158 & 0.103 & 0.055 & 0.286 & 0.253 & 0.033 & 1.03 & 1.11 & -0.08 & 8.22 & 12.39 & -4.17 \\
\hline 1984 & 0.048 & 0.036 & 0.013 & 0.059 & 0.034 & 0.025 & 0.151 & 0.114 & 0.037 & 0.374 & 0.253 & 0.121 & 1.01 & 1.09 & -0.08 & 8.56 & 10.98 & -2.42 \\
\hline 1985 & 0.037 & 0.034 & 0.003 & 0.036 & 0.030 & 0.006 & 0.136 & 0.107 & 0.028 & 0.247 & 0.252 & -0.005 & 1.01 & 1.16 & -0.15 & 8.18 & 13.63 & -5.45 \\
\hline 1986 & 0.039 & 0.033 & 0.006 & 0.039 & 0.028 & 0.011 & 0.141 & 0.102 & 0.040 & 0.254 & 0.254 & 0.000 & 1.03 & 1.23 & -0.20 & 9.24 & 14.78 & -5.54 \\
\hline 1987 & 0.052 & 0.039 & 0.013 & 0.063 & 0.031 & 0.032 & 0.177 & 0.105 & 0.072 & 0.145 & 0.269 & -0.124 & 1.19 & 1.18 & 0.01 & 9.87 & 12.59 & -2.72 \\
\hline 1988 & 0.060 & 0.043 & 0.017 & 0.075 & 0.032 & 0.043 & 0.190 & 0.113 & 0.077 & 0.155 & 0.272 & -0.117 & 1.08 & 1.22 & -0.14 & 6.63 & 12.36 & -5.73 \\
\hline 1989 & 0.068 & 0.041 & 0.027 & 0.080 & 0.031 & 0.049 & 0.212 & 0.107 & 0.105 & 0.157 & 0.269 & -0.112 & 1.16 & 1.27 & -0.11 & 7.84 & 13.62 & -5.78 \\
\hline 1990 & 0.054 & 0.034 & 0.020 & 0.067 & 0.026 & 0.040 & 0.199 & 0.090 & 0.109 & 0.150 & 0.264 & -0.114 & 1.14 & 1.13 & 0.01 & 8.30 & 11.88 & -3.59 \\
\hline 1991 & 0.055 & 0.030 & 0.025 & 0.064 & 0.021 & 0.042 & 0.166 & 0.078 & 0.088 & 0.136 & 0.268 & -0.131 & 1.21 & 1.17 & 0.04 & 10.07 & 14.34 & -4.28 \\
\hline 1992 & 0.048 & 0.028 & 0.020 & 0.053 & 0.020 & 0.033 & 0.136 & 0.074 & 0.062 & 0.128 & 0.269 & -0.141 & 1.12 & 1.14 & -0.02 & 11.20 & 14.45 & -3.24 \\
\hline 1993 & 0.052 & 0.032 & 0.020 & 0.057 & 0.019 & 0.038 & 0.127 & 0.077 & 0.049 & 0.130 & 0.273 & -0.143 & 1.12 & 1.22 & -0.09 & 11.32 & 16.11 & -4.79 \\
\hline 1994 & 0.055 & 0.038 & 0.017 & 0.057 & 0.023 & 0.033 & 0.128 & 0.085 & 0.043 & 0.131 & 0.281 & -0.150 & 1.35 & 1.22 & 0.13 & 14.85 & 14.61 & 0.24 \\
\hline 1995 & 0.056 & 0.040 & 0.015 & 0.064 & 0.024 & 0.040 & 0.141 & 0.086 & 0.055 & 0.136 & 0.282 & -0.146 & 1.32 & 1.19 & 0.13 & 12.61 & 13.99 & -1.38 \\
\hline 1996 & 0.053 & 0.040 & 0.013 & 0.063 & 0.024 & 0.040 & 0.158 & 0.083 & 0.074 & 0.129 & 0.288 & -0.159 & 1.33 & 1.24 & 0.09 & 12.62 & 14.70 & -2.08 \\
\hline 1997 & 0.056 & 0.038 & 0.018 & 0.056 & 0.022 & 0.035 & 0.143 & 0.083 & 0.060 & 0.158 & 0.297 & -0.139 & 1.28 & 1.22 & 0.06 & 12.54 & 15.19 & -2.64 \\
\hline 1998 & 0.056 & 0.030 & 0.026 & 0.048 & 0.016 & 0.032 & 0.117 & 0.070 & 0.046 & 0.165 & 0.308 & -0.143 & 1.18 & 1.12 & 0.07 & 8.20 & 11.38 & -3.18 \\
\hline 1999 & 0.060 & 0.032 & 0.028 & 0.043 & 0.016 & 0.027 & 0.129 & 0.069 & 0.060 & 0.166 & 0.312 & -0.146 & 1.12 & 1.14 & -0.02 & 7.98 & 10.36 & -2.38 \\
\hline 2000 & 0.042 & 0.032 & 0.010 & 0.039 & 0.016 & 0.023 & 0.129 & 0.065 & 0.064 & 0.250 & 0.314 & -0.064 & 1.05 & 1.09 & -0.03 & 6.29 & 8.37 & -2.09 \\
\hline 2001 & 0.036 & 0.024 & 0.011 & 0.039 & 0.012 & 0.027 & 0.126 & 0.053 & 0.072 & 0.290 & 0.310 & -0.020 & 1.01 & 1.07 & -0.06 & 5.34 & 7.44 & -2.10 \\
\hline 2002 & 0.034 & 0.024 & 0.010 & 0.039 & 0.012 & 0.027 & 0.115 & 0.051 & 0.064 & 0.321 & 0.308 & 0.014 & 1.01 & 1.06 & -0.04 & 5.88 & 7.44 & -1.57 \\
\hline 2003 & 0.033 & 0.029 & 0.003 & 0.041 & 0.016 & 0.024 & 0.126 & 0.061 & 0.065 & 0.315 & 0.314 & 0.002 & 1.07 & 1.16 & -0.09 & 6.26 & 10.74 & -4.48 \\
\hline 2004 & 0.048 & 0.021 & 0.027 & 0.062 & 0.019 & 0.043 & 0.138 & 0.050 & 0.088 & 0.382 & 0.231 & 0.151 & 1.06 & 1.01 & 0.05 & 6.89 & 16.79 & -9.90 \\
\hline & 0.051 & 0.033 & 0.018 & 0.057 & 0.024 & 0.032 & 0.155 & 0.087 & 0.068 & 0.270 & 0.276 & -0.006 & 1.13 & 1.14 & -0.01 & 8.66 & 12.20 & -3.55 \\
\hline
\end{tabular}


Table 6: Firm Level (Worldscope) Evidence on Profitability: The Level of Profitability - Variation Across Firm Size and Time

\begin{tabular}{|c|c|c|c|c|c|c|c|}
\hline \multicolumn{8}{|c|}{ Net Income/Sales } \\
\hline & AF & & & World & & & \\
\hline & Large & Small & Diff & Large & Small & Diff & Diff in Diff \\
\hline 1980 & 0.053 & 0.064 & -0.012 & 0.037 & 0.041 & -0.004 & -0.008 \\
\hline 1981 & 0.055 & 0.090 & -0.035 & 0.035 & 0.038 & -0.003 & -0.033 \\
\hline 1982 & 0.034 & 0.068 & -0.035 & 0.028 & 0.035 & -0.006 & -0.028 \\
\hline 1983 & 0.031 & 0.081 & -0.050 & 0.029 & 0.036 & -0.008 & -0.043 \\
\hline 1984 & 0.034 & 0.067 & -0.033 & 0.033 & 0.040 & -0.007 & -0.025 \\
\hline 1985 & 0.031 & 0.051 & -0.020 & 0.030 & 0.039 & -0.009 & -0.012 \\
\hline 1986 & 0.041 & 0.043 & -0.002 & 0.031 & 0.038 & -0.007 & 0.005 \\
\hline 1987 & 0.051 & 0.060 & -0.008 & 0.036 & 0.042 & -0.006 & -0.003 \\
\hline 1988 & 0.055 & 0.082 & -0.027 & 0.042 & 0.046 & -0.004 & -0.023 \\
\hline 1989 & 0.059 & 0.090 & -0.031 & 0.039 & 0.044 & -0.005 & -0.026 \\
\hline 1990 & 0.049 & 0.074 & -0.024 & 0.032 & 0.037 & -0.004 & -0.020 \\
\hline 1991 & 0.050 & 0.068 & -0.018 & 0.028 & 0.031 & -0.004 & -0.014 \\
\hline 1992 & 0.045 & 0.055 & -0.010 & 0.027 & 0.030 & -0.003 & -0.007 \\
\hline 1993 & 0.047 & 0.057 & -0.010 & 0.030 & 0.033 & -0.003 & -0.007 \\
\hline 1994 & 0.049 & 0.058 & -0.009 & 0.038 & 0.038 & 0.000 & -0.009 \\
\hline 1995 & 0.059 & 0.054 & 0.005 & 0.041 & 0.039 & 0.002 & 0.003 \\
\hline 1996 & 0.050 & 0.052 & -0.002 & 0.041 & 0.039 & 0.002 & -0.004 \\
\hline 1997 & 0.061 & 0.054 & 0.007 & 0.040 & 0.035 & 0.006 & 0.001 \\
\hline 1998 & 0.057 & 0.051 & 0.007 & 0.033 & 0.025 & 0.008 & -0.001 \\
\hline 1999 & 0.067 & 0.040 & 0.027 & 0.035 & 0.025 & 0.010 & 0.016 \\
\hline 2000 & 0.057 & 0.013 & 0.043 & 0.035 & 0.027 & 0.008 & 0.035 \\
\hline 2001 & 0.045 & 0.013 & 0.032 & 0.027 & 0.020 & 0.006 & 0.026 \\
\hline 2002 & 0.042 & 0.020 & 0.022 & 0.027 & 0.019 & 0.007 & 0.014 \\
\hline 2003 & 0.048 & 0.008 & 0.040 & 0.033 & 0.023 & 0.011 & 0.029 \\
\hline 2004 & 0.054 & 0.035 & 0.020 & 0.021 & 0.021 & 0.000 & 0.019 \\
\hline & 0.049 & 0.054 & -0.005 & 0.033 & 0.034 & 0.000 & -0.005 \\
\hline
\end{tabular}


Table 7: Listed Firm vs. Industry (All Firm) Profitability by Industry

Food products

Beverages

Tobacco

Textiles

Footwear, except rubber or plastic

Wood products, except furniture

Furniture, except metal

Paper and products

Printing and publishing

Industrial chemicals

Other chemicals

Misc. petroleum and coal products

Rubber products

Plastic products

Pottery, china, earthenware

Glass and products

Other non-metallic mineral products

Iron and steel

Non-ferrous metals

Machinery, except electrical

Machinery, electric

Transport equipment

Professional \& scientific equipment

Other manufactured products

Wearing apparel and Leather Products

Average
Operating Income (Listed) /Sales \& Value Added/Output (All) ZAF

$\begin{array}{lcccccc}\text { Listed } & \text { All } & \text { Ratio } & \text { Listed } & \text { All } & \text { Ratio } & \text { Ratio of Re } \\ 0.084 & 0.126 & 0.67 & 0.050 & 0.162 & 0.31 & 2.1 \\ 0.110 & 0.227 & 0.49 & 0.077 & 0.361 & 0.21 & 2.3 \\ 0.099 & 0.082 & 1.21 & 0.129 & 0.463 & 0.28 & 4.3 \\ 0.056 & 0.145 & 0.39 & 0.052 & 0.205 & 0.25 & 1.5 \\ 0.097 & 0.170 & 0.57 & 0.070 & 0.187 & 0.37 & 1.5 \\ 0.047 & 0.107 & 0.44 & 0.049 & 0.205 & 0.24 & 1.9 \\ 0.067 & 0.065 & 1.03 & 0.066 & 0.209 & 0.32 & 3.3 \\ 0.098 & 0.192 & 0.51 & 0.067 & 0.206 & 0.32 & 1.6 \\ 0.081 & 0.158 & 0.51 & 0.086 & 0.232 & 0.37 & 1.4 \\ 0.140 & 0.198 & 0.70 & 0.077 & 0.237 & 0.32 & 2.2 \\ 0.082 & 0.136 & 0.60 & 0.074 & 0.259 & 0.29 & 2.1 \\ 0.054 & 0.228 & 0.24 & 0.078 & 0.207 & 0.37 & 0.6 \\ 0.115 & 0.173 & 0.66 & 0.055 & 0.225 & 0.25 & 2.7 \\ 0.080 & 0.157 & 0.51 & 0.063 & 0.227 & 0.28 & 1.8 \\ 0.116 & 0.201 & 0.58 & 0.060 & 0.289 & 0.21 & 2.8 \\ 0.175 & 0.368 & 0.48 & 0.093 & 0.277 & 0.34 & 1.4 \\ 0.098 & 0.209 & 0.47 & 0.065 & 0.267 & 0.24 & 1.9 \\ 0.091 & 0.277 & 0.33 & 0.050 & 0.187 & 0.27 & 1.2 \\ 0.077 & 0.379 & 0.20 & 0.049 & 0.169 & 0.29 & 0.7 \\ 0.045 & 0.199 & 0.23 & 0.051 & 0.222 & 0.23 & 1.0 \\ 0.066 & 0.067 & 0.98 & 0.056 & 0.226 & 0.25 & 3.9 \\ 0.054 & 0.115 & 0.47 & 0.050 & 0.184 & 0.27 & 1.7 \\ 0.084 & 0.409 & 0.20 & 0.068 & 0.252 & 0.27 & 0.8 \\ 0.071 & 0.454 & 0.16 & 0.059 & 0.223 & 0.26 & 0.6 \\ 0.050 & 0.136 & 0.37 & 0.059 & 0.183 & 0.32 & 1.2 \\ & & & & & & \\ 0.085 & 0.199 & 0.52 & 0.059 & 0.234 & 0.29 & 1.9\end{array}$




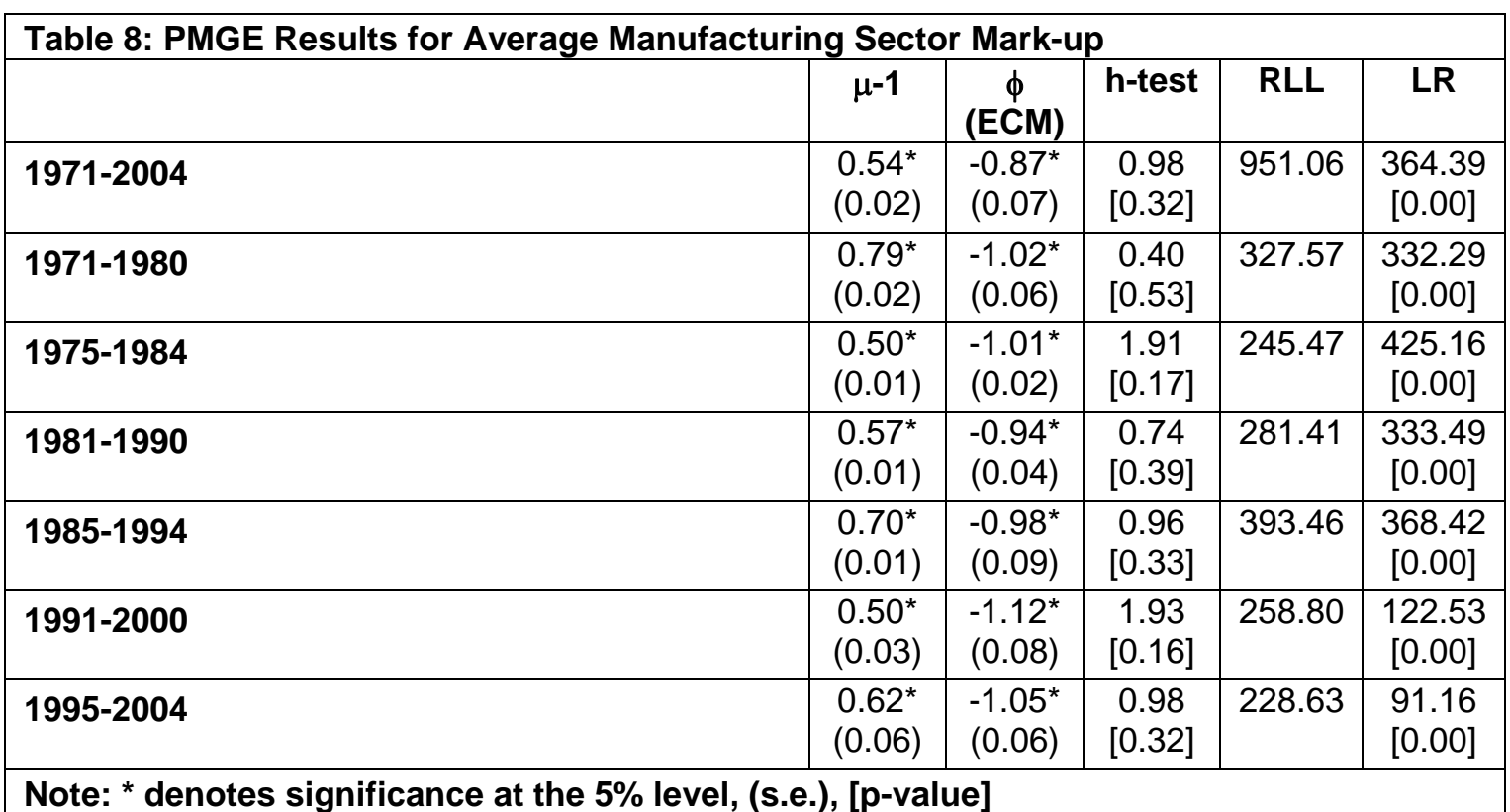




\begin{tabular}{|l|c|c|c|c|}
\hline \multirow{2}{*}{$\begin{array}{l}\text { Table 9: ADF Test Statistic } \\
\text { (using AIC(5) to select lag order) }\end{array}$} & \multicolumn{3}{|c|}{ Variable: } \\
\hline Manufacturing 3-digit Sectors & $\mathbf{I}(\mathbf{0})$ & $\mathbf{I}(\mathbf{1})$ & $\mathbf{I}(\mathbf{0})$ & $\mathbf{I}(\mathbf{1})$ \\
\hline Food & -4.66 & & -5.45 & \\
\hline Beverages & -4.67 & & -5.35 & \\
\hline Tobacco & -5.07 & & -6.61 & \\
\hline Textiles & -3.95 & & -5.84 & \\
\hline Wearing apparel & -4.03 & & -5.78 & \\
\hline Leather \& leather products & -4.55 & & -5.82 & \\
\hline Footwear & -3.00 & & -5.61 & \\
\hline Wood \& wood products & -4.67 & & -5.16 & \\
\hline Paper \& paper products & -4.10 & & -4.71 & \\
\hline Printing, publishing \& recorded media & -4.55 & & -4.54 & \\
\hline Coke \& refined petroleum & -5.62 & & -5.55 & \\
\hline Basic chemicals & -4.73 & & -5.98 & \\
\hline Other chemicals \& man-made fibers & -4.76 & & -5.84 & \\
\hline Rubber products & -4.67 & & -4.80 & \\
\hline Plastic products & -3.91 & & -4.86 & \\
\hline Glass \& glass products & -3.57 & & -5.59 & \\
\hline Non-metallic minerals & -3.81 & & -5.44 & \\
\hline Basic iron \& steel & $-2.77 *$ & -6.48 & -5.64 & \\
\hline Basic non-ferrous metals & -5.02 & & -5.20 & \\
\hline Metal products excluding machinery & -4.41 & & -5.52 & \\
\hline Machinery \& equipment & -4.92 & & -5.46 & \\
\hline Electrical machinery \& apparatus & & & & \\
\hline Television, \& communication equipment & -4.47 & & -4.94 & \\
\hline Professional \& scientific equipment & -4.77 & & -7.31 & \\
\hline Motor vehicles, parts \& accessories & -3.26 & & -5.31 & \\
\hline Other transport equipment & -5.07 & & -4.21 & \\
\hline Furniture & -3.93 & & -5.32 & \\
\hline Other manufacturing & -5.62 & & -5.73 & \\
\hline Note: * denotes rejection of the null of no unit root & & & & \\
\hline
\end{tabular}




\begin{tabular}{|c|c|c|c|c|c|c|c|c|}
\hline Manufacturing 3-digit Sectors & 1971-2004 & (s.e.) & 1971-1980 & 1975-1984 & $1981-1990$ & 1985-1994 & $1991-2000$ & 1995-2004 \\
\hline Food & $0.86^{*}$ & $(0.10)$ & 0.79 & 0.87 & 0.61 & 0.70 & 0.68 & 1.08 \\
\hline Beverages & $1.07^{*}$ & $(0.12)$ & 1.45 & 1.47 & 0.97 & 1.30 & 1.17 & 2.29 \\
\hline Tobacco & $4.05^{\star}$ & $(0.58)$ & 4.27 & 0.73 & 5.03 & 3.79 & 2.16 & -7.79 \\
\hline Textiles & $0.51^{*}$ & $(0.06)$ & 0.49 & 0.56 & 0.30 & 0.39 & 0.82 & 1.26 \\
\hline Wearing apparel & $0.29 *$ & $(0.07)$ & 0.35 & 0.29 & 0.19 & 0.26 & 0.24 & 0.63 \\
\hline Leather \& leather products & $0.16^{*}$ & $(0.03)$ & 0.17 & 0.13 & 0.21 & 0.26 & 0.07 & -0.25 \\
\hline Footwear & $0.14^{*}$ & $(0.04)$ & 0.10 & 0.14 & 0.10 & 0.15 & -0.69 & 0.47 \\
\hline Wood \& wood products & $0.55^{\star}$ & $(0.06)$ & 0.93 & 0.79 & 0.59 & 0.77 & -0.24 & 0.22 \\
\hline Paper \& paper products & $0.84^{*}$ & $(0.09)$ & 0.17 & 0.81 & 0.73 & 0.81 & 1.02 & 1.19 \\
\hline Printing, publishing \& recorded media & $0.28^{*}$ & $(0.06)$ & 0.35 & 0.39 & 0.31 & 0.45 & 1.19 & 0.07 \\
\hline Coke \& refined petroleum & $3.31^{*}$ & $(0.60)$ & 1.55 & 2.90 & 2.93 & 2.98 & 4.74 & 2.12 \\
\hline Basic chemicals & $0.83^{*}$ & $(0.11)$ & 0.89 & 0.79 & 0.34 & 0.84 & 5.05 & 0.59 \\
\hline Other chemicals \& man-made fibers & $0.70^{*}$ & $(0.06)$ & 0.40 & 0.93 & 0.61 & 0.76 & 0.29 & 0.29 \\
\hline Rubber products & $0.52^{*}$ & $(0.06)$ & 0.58 & 0.60 & 0.42 & 0.48 & 0.03 & 0.07 \\
\hline Plastic products & $0.69 *$ & $(0.09)$ & 0.45 & 0.75 & 0.50 & 0.56 & 1.82 & 0.85 \\
\hline Glass \& glass products & ** & & 0.28 & 0.40 & 0.58 & 0.65 & 0.84 & 1.36 \\
\hline Non-metallic minerals & $0.96^{*}$ & $(0.25)$ & 0.70 & 0.79 & 0.58 & 0.62 & 0.29 & 1.03 \\
\hline Basic iron \& steel & $0.60^{*}$ & $(0.11)$ & 0.54 & 0.54 & 0.24 & 0.24 & 0.24 & 1.52 \\
\hline Basic non-ferrous metals & $0.77^{*}$ & $(0.12)$ & 2.75 & 1.35 & 0.76 & 1.16 & 0.62 & 1.55 \\
\hline Metal products excluding machinery & $0.41^{*}$ & $(0.05)$ & 0.44 & 0.46 & 0.32 & 0.40 & 0.30 & 0.79 \\
\hline Machinery \& equipment & $0.29 *$ & $(0.05)$ & 0.14 & 0.23 & 0.25 & 0.39 & 0.36 & 0.27 \\
\hline Electrical machinery \& apparatus & $0.49^{*}$ & $(0.05)$ & 0.93 & 0.72 & 0.45 & 0.62 & 0.38 & -0.01 \\
\hline Television, \& communication equipment & $0.46^{*}$ & $(0.05)$ & 0.28 & 0.39 & 0.44 & 0.42 & 0.53 & 0.52 \\
\hline Professional \& scientific equipment & $0.52^{*}$ & $(0.06)$ & 0.74 & 0.61 & 0.53 & 0.82 & 0.98 & 1.12 \\
\hline Motor vehicles, parts \& accessories & $0.39 *$ & $(0.10)$ & 0.46 & 0.42 & 0.19 & 0.51 & 0.74 & 1.41 \\
\hline Other transport equipment & $0.36^{*}$ & $(0.08)$ & 0.70 & 0.49 & 0.46 & 0.50 & -0.04 & 0.11 \\
\hline Furniture & $0.20^{*}$ & $(0.03)$ & 0.42 & 0.28 & 0.18 & 0.26 & 0.30 & 0.42 \\
\hline Other manufacturing & $2.16^{*}$ & $(0.19)$ & 3.12 & 2.00 & 2.09 & 3.28 & 5.73 & 4.50 \\
\hline
\end{tabular}




\begin{tabular}{|c|c|c|c|}
\hline & Change in mark-up from $1991-2000$ to $1995-2004$ & & \\
\hline $\begin{array}{l}\text { Level of mark-up in 1991- } \\
2000\end{array}$ & Increase & Decrease & Less than $10 \%$ change \\
\hline $\begin{array}{c}\text { High } \\
\text { (above 80\%) }\end{array}$ & $\begin{array}{c}\text { Beverages } \\
\text { Textiles } \\
\text { Paper } \\
\text { Glass } \\
\text { Pro and sci eq } \\
\text { Furniture }\end{array}$ & $\begin{array}{c}\text { Tobacco } \\
\text { Printing } \\
\text { Coke }^{\star \star} \\
\text { Basic chemicals**} \\
\text { Plastic* } \\
\text { Other } \\
\text { manufacturing** }\end{array}$ & \\
\hline Medium & $\begin{array}{c}\text { Food } \\
\text { Basic non-ferrous metals } \\
\text { Motor }\end{array}$ & & Television, \& comm eq \\
\hline $\begin{array}{c}\text { Low } \\
\text { (below 40\%) }\end{array}$ & $\begin{array}{c}\text { Wearing apparel } \\
\text { Footwear } \\
\text { Wood* } \\
\text { Non-metallic minerals } \\
\text { Basic iron and steel } \\
\text { Metal } \\
\text { Other transport eq }\end{array}$ & Leather & $\begin{array}{l}\text { Chemicals** } \\
\text { Rubber** } \\
\text { Machinery }\end{array}$ \\
\hline $\begin{array}{l}\text { Note: } \\
{ }^{*} \text { change is off singular low } \\
{ }^{* *} \text { change does not reflect } t r\end{array}$ & $\begin{array}{l}\text { entire series should be looked at } \\
\text { ent }\end{array}$ & & \\
\hline
\end{tabular}




\begin{tabular}{|c|c|c|c|c|c|c|c|}
\hline \multicolumn{8}{|c|}{\begin{tabular}{l|l} 
Table 12: LProxy Measures by Industry \\
\end{tabular}} \\
\hline & $\begin{array}{r}1970- \\
2004\end{array}$ & $\begin{array}{l}1970- \\
1979\end{array}$ & $\begin{array}{l}1975- \\
1984\end{array}$ & $\begin{array}{l}1980- \\
1989\end{array}$ & $\begin{array}{l}1985- \\
1994\end{array}$ & $\begin{array}{l}1990- \\
1999\end{array}$ & $\begin{array}{l}1995- \\
2004\end{array}$ \\
\hline Food & 0.33 & 0.33 & 0.35 & 0.35 & 0.33 & 0.30 & 0.32 \\
\hline Beverages & 0.48 & 0.48 & 0.47 & 0.47 & 0.48 & 0.48 & 0.47 \\
\hline Tobacco & 0.82 & 0.83 & 0.79 & 0.79 & 0.79 & 0.80 & 0.84 \\
\hline Textiles & 0.19 & 0.22 & 0.23 & 0.21 & 0.20 & 0.13 & 0.12 \\
\hline Wearing Apparel & 0.15 & 0.14 & 0.14 & 0.15 & 0.18 & 0.16 & 0.15 \\
\hline Leather \& leather products & 0.20 & 0.05 & 0.07 & 0.13 & 0.20 & 0.29 & 0.39 \\
\hline Footwear & 0.16 & 0.05 & 0.07 & 0.09 & 0.12 & 0.19 & 0.36 \\
\hline Wood \& wood products & 0.29 & 0.23 & 0.28 & 0.34 & 0.36 & 0.33 & 0.26 \\
\hline Paper \& paper products & 0.33 & 0.28 & 0.32 & 0.32 & 0.34 & 0.34 & 0.37 \\
\hline Printing \& publishing & 0.20 & 0.17 & 0.19 & 0.22 & 0.25 & 0.27 & 0.18 \\
\hline Coke \& refined petroleum & 0.22 & 0.43 & 0.43 & 0.41 & 0.21 & -0.18 & -0.07 \\
\hline Basic chemicals & 0.23 & 0.30 & 0.26 & 0.16 & 0.15 & 0.18 & 0.25 \\
\hline Other chemicals & 0.29 & 0.29 & 0.29 & 0.28 & 0.29 & 0.29 & 0.30 \\
\hline Rubber products & 0.25 & 0.26 & 0.27 & 0.27 & 0.25 & 0.25 & 0.23 \\
\hline Plastic products & 0.29 & 0.30 & 0.33 & 0.33 & 0.33 & 0.29 & 0.20 \\
\hline Glass \& glass products & 0.22 & 0.16 & 0.22 & 0.26 & 0.29 & 0.20 & 0.21 \\
\hline Non metallic mineral products & 0.24 & 0.24 & 0.26 & 0.22 & 0.17 & 0.16 & 0.28 \\
\hline Basic iron \& steel & 0.12 & 0.16 & 0.16 & 0.13 & 0.09 & -0.02 & 0.10 \\
\hline Basic non-ferrous metals & 0.32 & 0.19 & 0.31 & 0.36 & 0.35 & 0.32 & 0.42 \\
\hline Metal products & 0.23 & 0.19 & 0.21 & 0.23 & 0.24 & 0.25 & 0.26 \\
\hline Machinery \& equipment & 0.21 & 0.20 & 0.19 & 0.20 & 0.23 & 0.22 & 0.21 \\
\hline Electrical machinery & 0.31 & 0.30 & 0.31 & 0.31 & 0.29 & 0.31 & 0.33 \\
\hline Television \& comms equipment & 0.26 & 0.20 & 0.26 & 0.29 & 0.29 & 0.25 & 0.26 \\
\hline Professinal \& scientific equip. & 0.32 & 0.26 & 0.28 & 0.33 & 0.37 & 0.33 & 0.35 \\
\hline Motor vehicles & 0.21 & 0.15 & 0.15 & 0.14 & 0.22 & 0.27 & 0.30 \\
\hline Other transport industry & 0.26 & 0.38 & 0.31 & 0.34 & 0.33 & 0.16 & 0.07 \\
\hline Furniture & 0.19 & 0.14 & 0.15 & 0.17 & 0.20 & 0.23 & 0.23 \\
\hline Other manufacturing & 0.71 & 0.62 & 0.65 & 0.70 & 0.75 & 0.77 & 0.77 \\
\hline
\end{tabular}


Table 13: Margins and Growth. Industry Evidence.

\begin{tabular}{|c|c|c|c|c|c|c|c|c|}
\hline \multicolumn{9}{|c|}{ Dependent Variable: Real Labor Productivity Growth } \\
\hline \multirow[b]{2}{*}{ Price-Cost Margin t-1 } & \multicolumn{3}{|c|}{ Sample of 115 countries } & \multicolumn{4}{|c|}{ South Africa } & \\
\hline & $\begin{array}{l}-0.996 \star \star \star * \\
0.181\end{array}$ & $\begin{array}{l}-0.638 * \star \star \\
0.073\end{array}$ & $\begin{array}{c}-0.835 \\
0.130\end{array}$ & $* \star *$ & $\begin{array}{l}-0.798 \text { * } \\
0.413\end{array}$ & $\begin{array}{c}-0.767 \star \star * \star \\
0.212\end{array}$ & $\begin{array}{l}-1.279 \\
0.441\end{array}$ & $\star * *$ \\
\hline$(\text { Price-Cost Margin t-1) })^{2}$ & & & $\begin{array}{c}0.330 \\
0.169\end{array}$ & * & & & $\begin{array}{c}0.992 \\
0.556\end{array}$ & * \\
\hline Country Fixed Effects & Yes & Yes & Yes & & - & - & - & \\
\hline Industry Fixed Effects & No & Yes & Yes & & No & Yes & Yes & \\
\hline Year Fixed Effects & Yes & Yes & Yes & & No & Yes & Yes & \\
\hline \# Observations & 1615 & 38520 & 38520 & & 27 & 630 & 630 & \\
\hline \# Industries & 1 & 27 & 27 & & 1 & 27 & 27 & \\
\hline $\mathrm{R} 2$ & 0.40 & 0.15 & 0.15 & & 0.13 & 0.22 & 0.23 & \\
\hline
\end{tabular}


Table 14: Margins and Growth. Firm-Level Evidence.

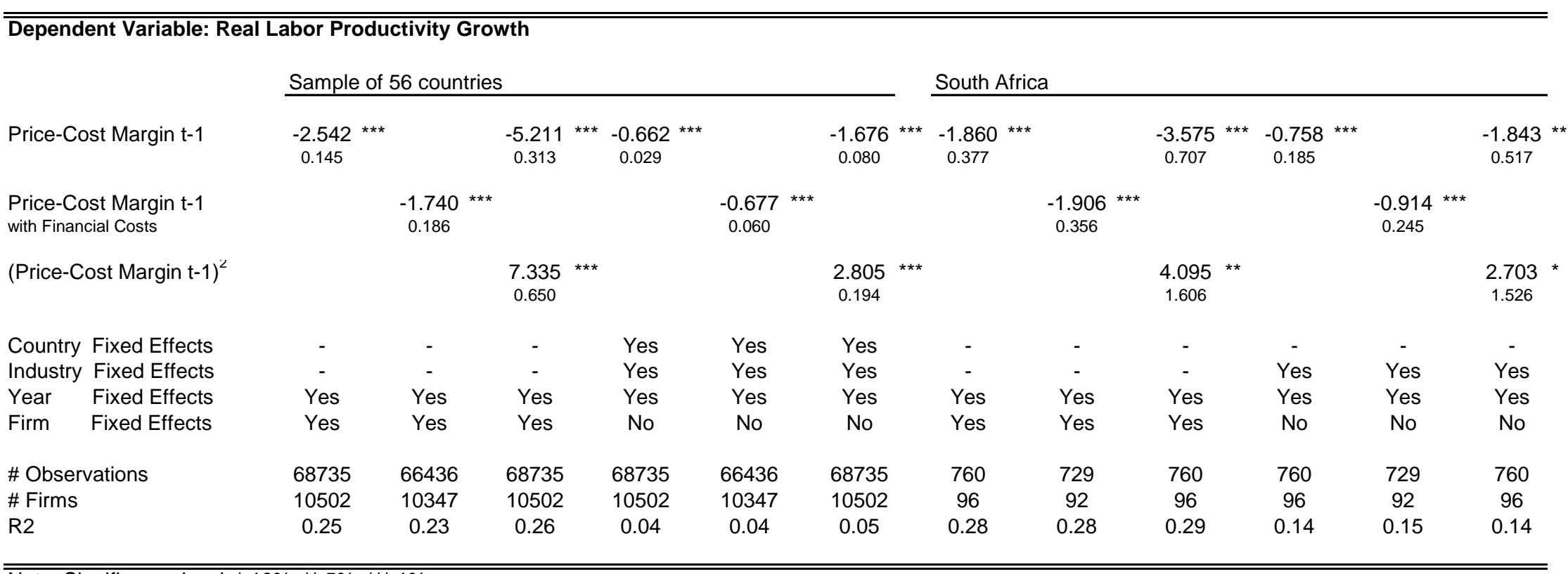

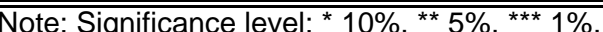

Errors are clustered at the country level and at the year level for the Sample of 56 countries and South Africa regressions, respectively. 
Table 15: Margins and Growth: IV Estimates

\begin{tabular}{|c|c|c|c|c|c|}
\hline \multicolumn{6}{|c|}{ Dependent Variable: Real Labor Productivity Growth } \\
\hline & \multicolumn{2}{|l|}{ Industry Data } & \multicolumn{3}{|c|}{ Firm-Level Data } \\
\hline & All Countries & South Africa & All Countries & & South Africa \\
\hline Price-Cost Margin t-1 & $\begin{array}{l}116.133 \\
2560.640\end{array}$ & $\begin{array}{c}-0.309 \\
0.697\end{array}$ & $\begin{array}{c}-0.854 \\
0.474\end{array}$ & * & $\begin{array}{c}0.234 \\
4.417\end{array}$ \\
\hline Country Fixed Effects & Yes & - & Yes & & - \\
\hline Industry Fixed Effects & Yes & Yes & Yes & & Yes \\
\hline Fixed Effects & Yes & Yes & Yes & & Yes \\
\hline Fixed Effects & - & - & No & & No \\
\hline \# Observations & 24831 & 546 & 42510 & & 650 \\
\hline $\mathrm{R} 2$ & 0.00 & 0.17 & 0.05 & & 0.12 \\
\hline First-stage Regressions & & & & & \\
\hline Coeff. of Instr. on Margins & 0.00 & 0.011 & -0.002 & $\star * *$ & -0.005 \\
\hline
\end{tabular}

Note: Significance level: * $10 \%$, ** $5 \%,{ }^{\star \star \star} 1 \%$.

Errors are clustered at the country level and at the year level for the Sample of "All Countries" and "South Africa" regressions, respectively. 
Figure 1: Margins and Growth in South Africa: Aggregate Industry Data

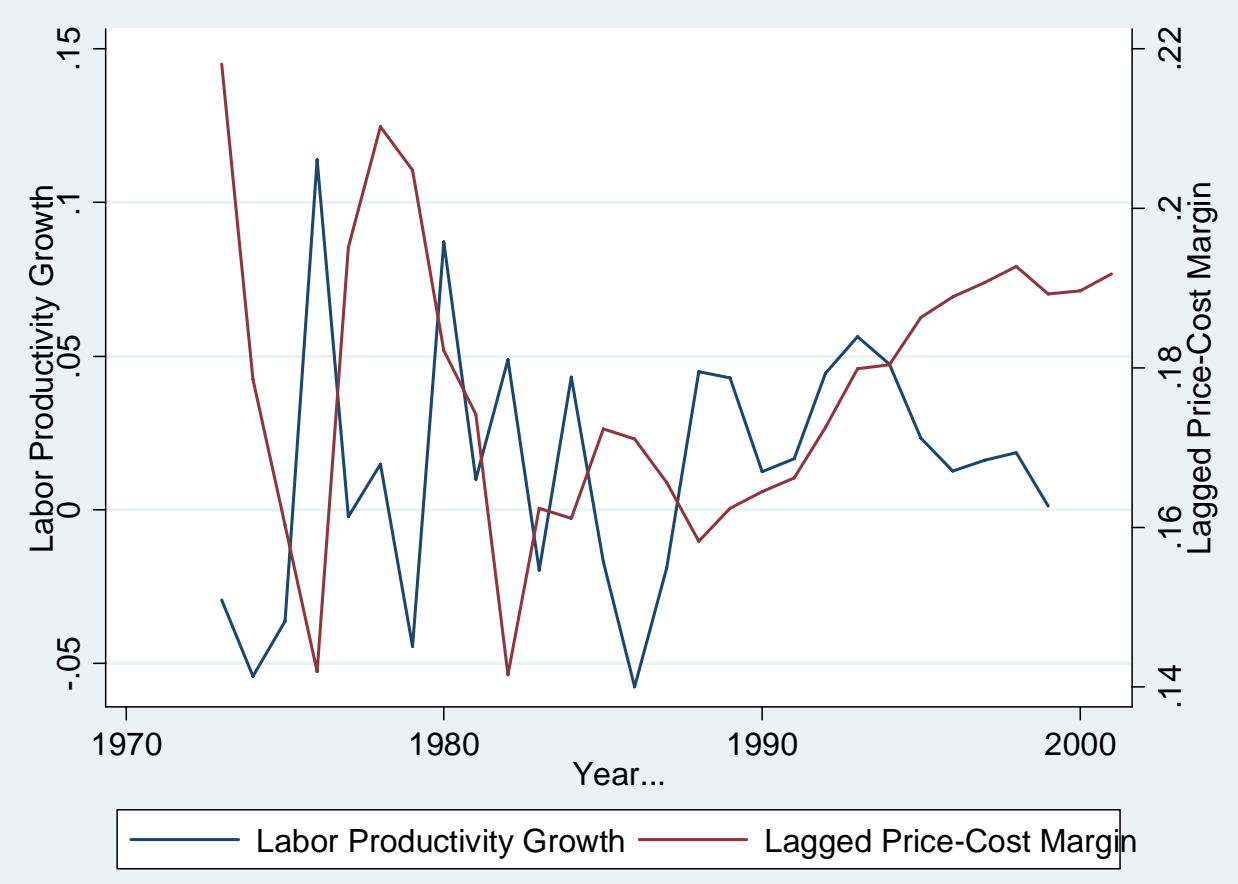


Figure 2: Margins and Growth in South Africa: Disaggregated Industry Data

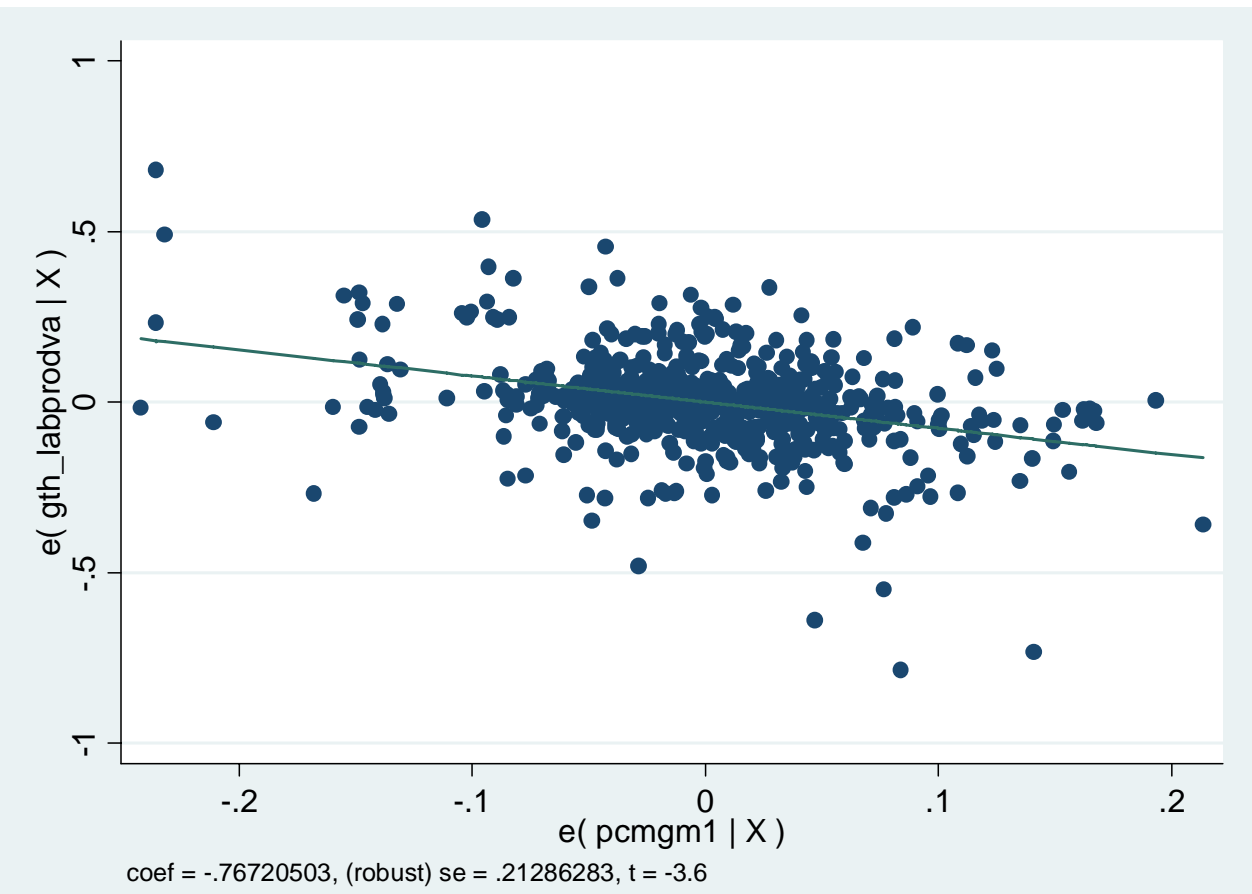




\begin{tabular}{|c|c|c|c|c|c|}
\hline & PMGE & $\begin{array}{c}\phi \\
\text { (ECM) }\end{array}$ & h-test & RLL & ULL \\
\hline & $\begin{array}{l}-0.10^{*} \\
(0.03)\end{array}$ & $\begin{array}{c}-0.71^{*} \\
(0.12)\end{array}$ & & & \\
\hline & MGE & $\begin{array}{c}\text { MGE ARDL lag } \\
\text { structure }\end{array}$ & & MGE & $\begin{array}{c}\text { MGE ARDL lag } \\
\text { structure }\end{array}$ \\
\hline Food & $\begin{array}{l}-0.27 \\
(0.19)\end{array}$ & 31 & Plas & $\begin{array}{l}-0.19 \\
(0.17)\end{array}$ & 01 \\
\hline Beve & $\begin{array}{l}-0.65 \\
(0.34)\end{array}$ & 02 & Glas & $\begin{array}{l}-0.10 \\
(0.12)\end{array}$ & 02 \\
\hline Toba & $\begin{array}{l}-0.02 \\
(0.57)\end{array}$ & 11 & Nonm & $\begin{array}{l}-0.21 \\
(0.11)\end{array}$ & 33 \\
\hline Text & $\begin{array}{c}0.13 \\
(0.14)\end{array}$ & 00 & Iron & $\begin{array}{l}-0.33 \\
(0.12)\end{array}$ & 03 \\
\hline Wear & $\begin{array}{c}0.21 \\
(0.14)\end{array}$ & 10 & Nonf & $\begin{array}{l}-0.07 \\
(0.09)\end{array}$ & 22 \\
\hline Leat & $\begin{array}{c}0.23 \\
(0.14)\end{array}$ & 00 & Meta & $\begin{array}{l}-0.43 \\
(0.28)\end{array}$ & 01 \\
\hline Foot & $\begin{array}{c}0.08 \\
(0.08)\end{array}$ & 01 & Mach & $\begin{array}{l}-0.14 \\
(0.18)\end{array}$ & 11 \\
\hline Wood & $\begin{array}{l}-0.01 \\
(0.14)\end{array}$ & 01 & Elec & $\begin{array}{c}0.11 \\
(0.24)\end{array}$ & 00 \\
\hline Pape & $\begin{array}{l}-0.27 \\
(0.16)\end{array}$ & 01 & Tele & $\begin{array}{c}0.64 \\
(0.15)\end{array}$ & 20 \\
\hline Prin & $\begin{array}{l}-0.04 \\
(0.12)\end{array}$ & 00 & Prof & $\begin{array}{l}-0.10 \\
(0.27)\end{array}$ & 11 \\
\hline Coke & $\begin{array}{l}-0.13 \\
(0.13)\end{array}$ & 10 & Moto & $\begin{array}{c}0.09 \\
(0.12)\end{array}$ & 21 \\
\hline Chem & $\begin{array}{l}-0.22 \\
(0.08)\end{array}$ & 33 & Ottr & $\begin{array}{l}-0.06 \\
(0.14)\end{array}$ & 01 \\
\hline Otch & $\begin{array}{l}-0.71 \\
(0.22)\end{array}$ & 13 & Furn & $\begin{array}{c}1.01 \\
(0.73)\end{array}$ & 33 \\
\hline Rubb & $\begin{array}{l}-0.09 \\
(0.45)\end{array}$ & 00 & Otma & -0.47 & 11 \\
\hline
\end{tabular}




\begin{tabular}{|c|c|c|c|c|c|}
\hline \multicolumn{6}{|c|}{ Table 17: Impact of Competitive Pressure on Employment } \\
\hline & PMGE & $\begin{array}{c}\phi \\
(E C M)\end{array}$ & h-test & RLL & ULL \\
\hline & \begin{tabular}{|l|}
-0.34 \\
$(0.07)$
\end{tabular} & $\begin{array}{c}-0.06 \\
(0.05)\end{array}$ & & & \\
\hline & MGE & MGE ARDL lag structure & & MGE & MGE ARDL lag structure \\
\hline Food & \begin{tabular}{|c|}
1.32 \\
$(3.64)$
\end{tabular} & 20 & Plas & $\begin{array}{l}-0.13 \\
(0.75)\end{array}$ & 10 \\
\hline Beve & $\begin{array}{c}1.88 \\
(4.92)\end{array}$ & 30 & Glas & $\left|\begin{array}{c}-5.14 \\
(103.54)\end{array}\right|$ & 10 \\
\hline Toba & $\begin{array}{c}-1.50 \\
(30.82)\end{array}$ & 12 & Nonm & $\begin{array}{l}-1.61 \\
(0.42)\end{array}$ & 10 \\
\hline Text & $\begin{array}{c}4.88 \\
(8.27)\end{array}$ & 10 & Iron & $\left|\begin{array}{c}-26.12 \\
(244.00)\end{array}\right|$ & 20 \\
\hline Wear & $\begin{array}{l}-0.49 \\
(0.69)\end{array}$ & 20 & Nonf & $\begin{array}{c}1.13 \\
(2.04)\end{array}$ & 13 \\
\hline Leat & $\begin{array}{l}-0.02 \\
(0.05)\end{array}$ & 31 & Meta & $\begin{array}{l}-3.94 \\
(3.84)\end{array}$ & 13 \\
\hline Foot & $\begin{array}{l}-0.49 \\
(0.24)\end{array}$ & 21 & Mach & $\begin{array}{l}-2.06 \\
(0.94)\end{array}$ & 33 \\
\hline Wood & $\begin{array}{l}-2.10 \\
(6.83)\end{array}$ & 12 & Elec & $\left|\begin{array}{c}8.94 \\
(31.86)\end{array}\right|$ & 20 \\
\hline Pape & $\begin{array}{c}1.29 \\
(1.17)\end{array}$ & 22 & Tele & $\begin{array}{l}-0.22 \\
(0.12)\end{array}$ & 10 \\
\hline Prin & $\begin{array}{l}-0.07 \\
(0.28)\end{array}$ & 32 & Prof & $\left|\begin{array}{c}-16.27 \\
(589.18)\end{array}\right|$ & 10 \\
\hline Coke & $\begin{array}{c}0.18 \\
(0.13)\end{array}$ & 20 & Moto & $\begin{array}{l}-0.34 \\
(0.38)\end{array}$ & 22 \\
\hline Chem & $\begin{array}{l}-0.21 \\
(0.11)\end{array}$ & 10 & Ottr & $\begin{array}{c}0.24 \\
(0.29)\end{array}$ & 20 \\
\hline Otch & $\begin{array}{c}0.30 \\
(0.74)\end{array}$ & 32 & Furn & $\begin{array}{l}-1.66 \\
(4.85)\end{array}$ & 12 \\
\hline Rubb & \begin{tabular}{|c}
-0.48 \\
$(0.29)$ \\
\end{tabular} & 20 & Otma & $\begin{array}{c}5.28 \\
(3.73) \\
\end{array}$ & 30 \\
\hline
\end{tabular}


Table 18: PMGE Results for Manufacturing Sector Labour Adjustment

\begin{tabular}{|c|c|c|c|c|c|}
\hline $1972-2004$ & $\beta 1$ & $\beta 2$ & $\sigma$-hat & $\begin{array}{l}\text { Lab adj ( } \sigma- \\
\text { hat) }\end{array}$ & $\begin{array}{c}\text { Lab adj } \\
(\sigma=1)\end{array}$ \\
\hline \multirow[t]{2}{*}{ AIC(1) } & $0.42^{*}$ & $-4.88^{*}$ & 0.70 & 3.43 & 4.88 \\
\hline & $(0.15)$ & $(0.15)$ & & & \\
\hline \multirow[t]{2}{*}{ AIC(2) } & $0.67^{*}$ & $-4.74^{*}$ & 0.60 & 2.84 & 4.74 \\
\hline & $(0.14)$ & $(0.15)$ & & & \\
\hline \multirow[t]{2}{*}{ AIC(3) } & $0.59^{*}$ & $-4.76^{\star}$ & 0.63 & 2.99 & 4.76 \\
\hline & $(0.14)$ & $(0.15)$ & & & \\
\hline
\end{tabular}

Table 19: PMGE Results for Manufacturing Sector Labour Adjustment

\begin{tabular}{|c|c|c|c|c|}
\hline \multirow[b]{2}{*}{ Sub-period } & \multicolumn{2}{|c|}{ Lab adj ("correct" $\sigma)^{*}$} & \multicolumn{2}{|c|}{ Lab adj $(\sigma=1)$} \\
\hline & AIC(1) & $\operatorname{AIC}(2)$ & AIC(1) & $\mathrm{AIC}(2)$ \\
\hline $1972-1986$ & 3.54 & 2.76 & 4.63 & 4.25 \\
\hline $1973-1987$ & 3.51 & 3.36 & 4.56 & 4.27 \\
\hline 1974-1988 & 3.71 & 4.06 & 4.40 & 4.06 \\
\hline $1975-1989$ & 3.35 & 2.75 & 4.34 & 4.33 \\
\hline $1976-1990$ & 3.28 & 2.17 & 4.32 & 3.35 \\
\hline 1977-1991 & 2.35 & 1.75 & 3.61 & 2.59 \\
\hline 1978-1992 & 2.50 & 2.02 & 4.13 & 2.77 \\
\hline 1979-1993 & 2.42 & 1.68 & 4.29 & 5.46 \\
\hline 1980-1994 & 2.43 & 1.13 & 4.84 & 1.87 \\
\hline 1981-1995 & 2.58 & 2.80 & 4.94 & 4.79 \\
\hline $1982-1996$ & 2.62 & 2.78 & 4.63 & 4.77 \\
\hline $1983-1997$ & 3.29 & 2.27 & 5.00 & 2.27 \\
\hline 1984-1998 & 2.72 & 2.43 & 4.84 & 4.19 \\
\hline 1985-1999 & 5.69 & 1.96 & 5.69 & 1.50 \\
\hline $1986-2000$ & 6.79 & 3.66 & 3.69 & 1.56 \\
\hline $1987-2001$ & 3.50 & 3.40 & 3.50 & 2.62 \\
\hline $1988-2002$ & 2.45 & 1.83 & 4.58 & 3.76 \\
\hline 1989-2003 & 4.23 & ** & 4.23 & ** \\
\hline 1990-2004 & ** & ** & ** & ** \\
\hline
\end{tabular}

